\title{
The Use of Talent Management Instruments and Procedures in Germany: A Broad Explorative Study of Effectiveness and Success Factors
}

\author{
Jens Landwehr \\ Faculty of Management, Economics and Social Sciences, Seminar of Personnel Economics and HRM, University of Cologne, Cologne, \\ Germany \\ Email address: \\ Jenslandwehr@me.com \\ To cite this article: \\ Jens Landwehr. The Use of Talent Management Instruments and Procedures in Germany: A Broad Explorative Study of Effectiveness and \\ Success Factors. Journal of Human Resource Management. Vol. 4, No. 6, 2016, pp. 77-99. doi: 10.11648/j.jhrm.20160406.12
}

Received: November 25, 2016; Accepted: December 7, 2016; Published: January 5, 2017

\begin{abstract}
While talent management has become a fixed term on HR agendas worldwide, it appears that that quality of talent management practices, infrastructure, and success measurements of talent management in German organizations is still low. This explorative empirical study - one of the largest ever done on this topic in Germany - shows that roles and responsibilities in the talent management process remain often unclear, processes and tools such as an IT infrastructure are often weak, and success measures are often not applied. But there is also surprising evidence that companies in Germany largely apply the wrong measures. It seems that in many German organizations, instruments and procedures are being applied which either have a rather neutral or even can have a counterproductive effect on talent management success. Reversely, instruments which can be linked empirically to talent management success, are not being applied as consistently as you would expect based on HR professionals knowledge on the subject matter. This paper presents the results of an explorative study on the scope of talent management in German organizations, the use of specific instruments and procedures, and links the use of instruments to various measures of success, most notably the assessment by talent management professionals. The results are both startling and surprising: Instruments most widespread in German organization are those which often have a neutral or even negative effect on talent management success. Starting with the question, how important talent management from the perspective of the organization, the study provides a detailed view on the use of specific measures and the processes applied by German organizations. Based on the responses of 125 participants of an online survey with talent managers and other HR professionals, we found a lack of commitment to talent management processes by leadership as a possible explanation for the state of talent management in Germany.
\end{abstract}

Keywords: Talent Management, Success Factors, Success Measures, Infrastructure, Information Technology, Benchmarking, HR Processes, Explorative Study

\section{Introduction}

While the majority of organizations in Germany apply some sort of talent management, objective success measures, IT support or even external benchmarking is used to a much lesser degree. As a result, the quality of talent management in German organizations is low, and also German employees are often unsatisfied with the HR talent management measures applied in their organizations (Deloitte LLC study series 2009, 2012).

Historically, talent management received little attention in
Germany when the McKinsey report on the 'War for Talents' was first published in 1997 and gained much attention McKinsey (Michaels, Handfield-Jones, \& Axelrod, 2001; Axelrod, Handfield-Jones, \& Michaels, 2002). In most industries, the talent shortage had not arrived at the time. During the boom years of 2001 and 2002, the labor shortage initially hit companies trying to fill technical and engineering roles. However, between 2001 and the crisis year 2009, talent management enjoyed increasing attention within the field of 
strategic personnel management.

Since the term was first used in 1997 in the context of the war of talents claimed by McKinsey, not a single consistent or concise definition of talent management has emerged (Aston, Morton 2005). Lewis \& Heckman (2006) identified a 'disturbing lack of clarity regarding the definition, scope, and overall goals of talent management', and identified three key streams of thought: Talent management as substitute for human resource management, talent management as the development of talent pools, and finally the management of talented people. Collings \& Mellahi, (2009) define talent management more precisely as 'activities and processes that involve the systematic identification of key positions' differentially contributing to the success of the organization, the development of talent pools, and the HR architecture or processes to help fill these positions.

Today, talent management strategies continue to be one of the areas within modern HR with particularly high interest. It seems quite paradoxical that despite the large professional interest, little research has been done to identify the real success factors of instruments and procedures, and how these link to financial benefits for the organization. In addition, there is largely a low theoretical understanding on how talent management practice differs across countries and links to culture. The literature defines talent management as strategic $\mathrm{HR}$ activities in the areas of recruiting, performance management, skill and competency management, compensation and succession management with the objective of balancing expectations of critical workforce segments with the requirements of the organization. Most authors explicitly separate talent management from strategic workforce planning which includes the long-term cost and benefit simulations of talent management and always includes both quantitative and qualitative talent criteria.

While the increase in importance is clear and backed by the results of this paper, the literature is unclear about its reasons (Festing, Schäfer \& Scullion, 2013). Organizations try to align their talent management programs to their needs, may it be driven either by requirements in the area of recruiting, succession management, personnel development, or diversity and are largely basing their approaches on different schools of thought.

Some authors link the increased interest in talent management to stronger demands from the business towards the HR function (as a support function). These demands include balancing the supply and demand of the workforce in light of the demographic change (Capelli, 2008) as well as HR process efficiency (Ulrich, 2008). Other authors link the increase of talent management largely to increasing demands from new generations of applicants' with changed values and preferences (Ng, Burke, 2005). Recently, authors assume that the interest for talent management could be based on an intended façade (Brunson, 1989).

The theoretical basis of talent programs is thin. A major driver for talent is clearly rewards theory, however recently it has been emphasized that monetary benefits are less responsible for good performance than internal motivators.
Other theoretical concepts educating good talent management are equilibrium theory, and goal achievement theory with very little self-determination theory, self-regulation theory (Van Nuland, 2010).

While the most commonly stated benefit of talent management is to identify, develop and retain the most valuable critical employees (Leigh 2009; Germain 2010), some authors stress how potentially harmful it can be for an organization to focus on a small group of people while the contribution of the others is ignored (Pfeffer 2001). Other studies are more pragmatic and emphasize the use of effective talent instruments (Stahl 2007).

In sum, these developments have led over the past years to a striking expansion of talent management systems and instruments in many organizations. However, in many instances the effectiveness of instruments is not clear and the most effective instruments are not necessarily used most often. Specifically, in German organizations talent management is applied for the wrong reasons such as external demands from the business whereas true understanding of cause and effect of talent processes are highly undervalued and not sufficiently understood especially with respect to younger applicants. This has led in Germany to the use of wrong of wrong instruments and procedures.

\section{Research Questions}

The aim of this study is to establish empirically the relationship between the use of specific instruments and procedures and objective success measures in Germany. In order to clarify the linkages between instruments and talent management success, we will draw separate hypotheses for different talent management components indicating quality, such as processes, infrastructure and instruments. Thus, we will try to explore the reason why companies in Germany systematically and consistently apply talent instruments and procedures which are counterproductive.

Initially, we measure today's weight of talent management in German organizations and establish a complete overview over the prevalence of specific instruments and procedures. By linking the use of instruments to several measures of success (assessment of talent management success, external recruiting rate, fluctuation), we - for the first time - identify several clear success factors of talent management. The aim is to both develop a structured approach to assessing the effectiveness of instruments, processes and procedures as well as identifying objective success factors.

We expect an increasing importance of talent management and low levels of infrastructure and commitment towards talent management roles. In addition, we expect relatively low use of success-critical instruments. Moreover, we also expect a relatively low use of other success factors as reason for the relatively low levels of contentedness with talent management processes.

While explorative by nature, this research started out by defining two main hypotheses explaining the rise of talent 
management with two different lines of thought. The study was designed to help identify factors either in support or in contradiction to one of these hypotheses. Thus, our research is guided by the following research questions and hypotheses:

Hypothesis 1: The importance of talent management is generally on the rise (even during crisis years which tends to produce a talent surplus). Talent management is more important now than before, due to various reasons (demands from the business, demands from employees/applicants).

Hypothesis 2: Talent management is neither managed (clear roles, low infrastructure) nor practiced well in German organizations, as success-critical instruments are less in use compared to other instruments. This is the reason, why talent management is not successful in the eyes of management and employees.

\section{Methods}

\section{Sample}

In the spring of 2009, the department for personnel management at the University of Cologne contacted the personnel departments of the largest 1200 companies in Germany - measured by revenue. Initially, only the objectives of the study were revealed with the request to identify the talent manager or expert. In about 260 cases, a talent manager or expert was identified to whom the online questionnaire with the 52 questions was sent. Of this group, about one half completed the online survey (125), resulting in a response rate of almost $50 \%$. One third of the participants identified as talent managers, another third as other HR professionals and another third as personnel managers or general managers. The average number of employees of the participating organizations was about 20,000, with all major industries being represented.

The study also assesses the effectiveness of instruments and identifies several success factors of talent management from the perspective of HR professionals.

Figure 1 provides an overview of the participating industries; Figure 2 shows a breakdown by company size:

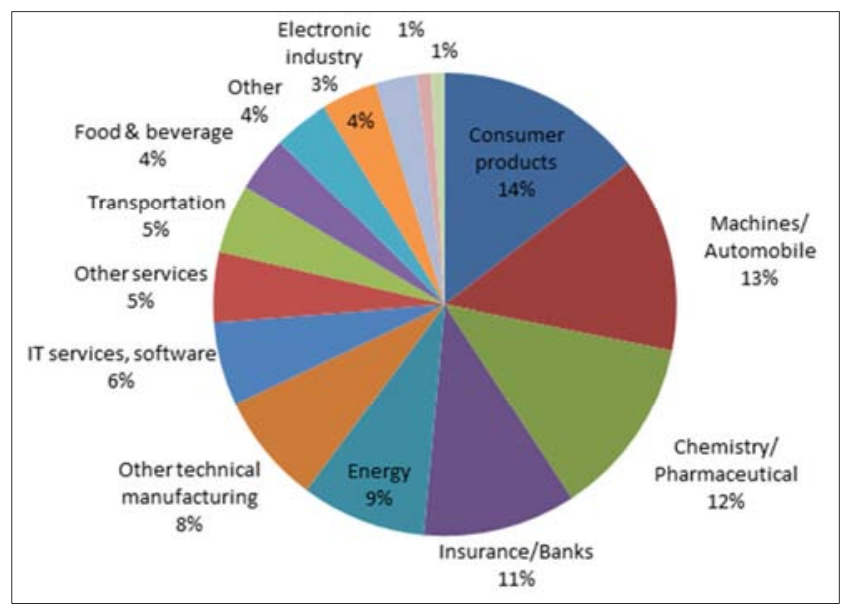

Figure 1. Overview of the participating industries.

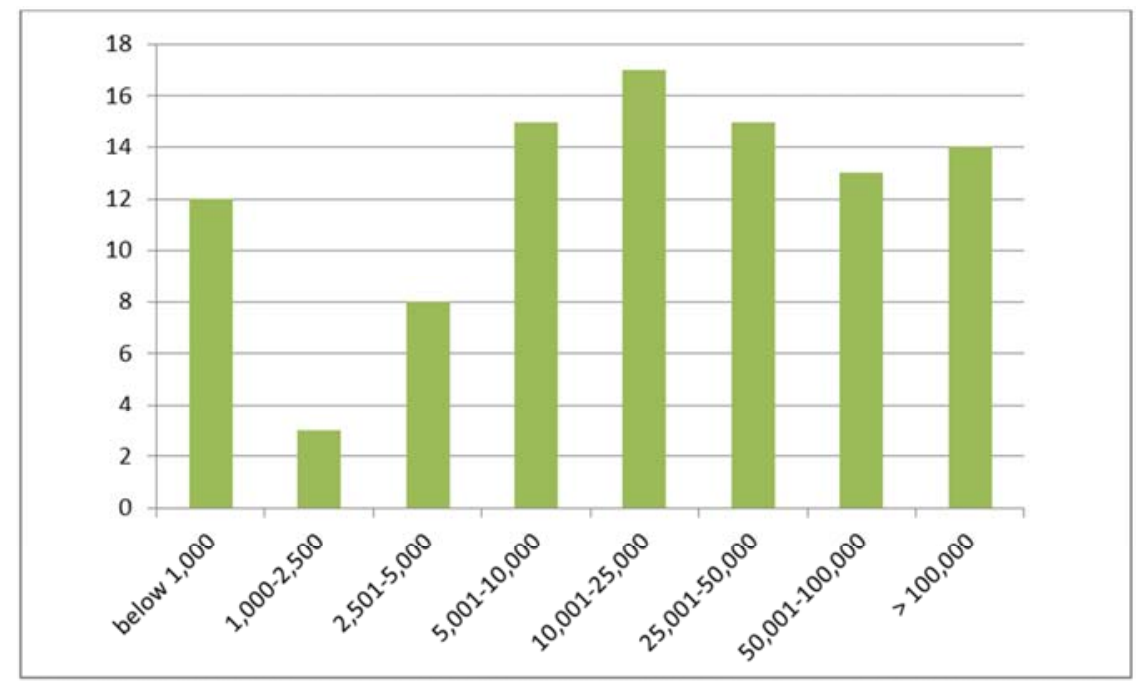

Figure 2. Breakdown by company size (number of employees).

The collection of data was carried out between March and May 2009. The participants were asked to take about 30 minutes for answering the questions, which were structured in 5 parts:

- Assessment of the importance of talent management (in the organization)

- Identification of instruments and processes used

- Objectives of talent management

- Success factors

- Socio demographic data of the participating individuals and organizations

\section{Design and Procedure}

In the first part of the questionnaire, participants were asked to subjectively assess the importance of talent management in their organizations (cf. Table 1a). This section also included questions about the target groups of talent management, responsibilities in the talent management process, the infrastructure for talent management and the general attitude towards talent management across the 
hierarchy of the organization.

In the second part of the questionnaire, participants were asked to identify the instruments in use for different target groups based on a list of 32 instruments grouped into 5 process areas (cf. Table 1b). In addition, participants were asked separately to identify the most effective and ineffective instruments from their perspective. In addition, in this section the participants were also asked to differentiate between their own, top management's and overall employee's perspective.

In the third part, the orientation of talent management and reasons for preferences from the perspective of HR were assessed. The questions in this section were chosen to identify success-critical processes and procedures and to collect key metrics (cf. Table 1c). In this section, too, the participants were asked to differentiate between their own, top management's and overall employee's perspective.

The fourth part, participant's views about the effectiveness of instruments, processes and procedures - such as successes of talent management - were assessed.

\section{Measures}

\subsection{Use of Instruments}

Participants were asked to state the use of instruments by target group (top and senior management; middle management; employees without management responsibility).

\subsection{Coverage of Processes and Procedures (Target Groups)}

Participants were asked on the basis of a 5 item scale (from strongly agree or strongly disagree) to agree or disagree to statements on the use of processes and procedures as well as target groups for talent management.

\subsection{Success of Talent Management}

In order to generate a viable and reliable indicator for success, we asked as a first step the talent managers or other respondents of the survey for their assessment of the talent management success ('How do you assess the success of talent management in your organization?'). In a second step, this subjective assessment of success was analyzed for consistency with other objective (quantitative) success metrics as well as comparisons of practices and procedures in successful versus less successful companies. The success indicator used correlates strongly and significantly $\mathrm{n}$ the expected directions: For example, it correlates negatively with external recruitment of candidates and positively with employee satisfaction and employer attractiveness and was thus deemed valid for this purpose. Figure 3 provides an overview over all correlations.

\begin{tabular}{|c|c|}
\hline External fillment of jobs - Middle Management & Mean $=37 \%$ \\
\hline External fillment of jobs - Senior Management & Mean $=48 \%$ \\
\hline $\begin{array}{r}\text { External fillment of jobs - Employees without } \\
\text { managerial responsibility }\end{array}$ & Mean $=17 \%$ \\
\hline $\begin{array}{l}\text { Labor turnover rate for employees from talent } \\
\text { pools }\end{array}$ & Mean $=9 \%$ \\
\hline $\begin{array}{r}\text { Labor turnover rate for miscellaneous } \\
\text { employees }\end{array}$ & Mean $=8 \%$ \\
\hline High employee satisfaction & Mean $=3,51$ \\
\hline Vacancies can be fastly filled & Mean $=3,41$ \\
\hline Culture of innovation is strongly developed & Mean $=3,32$ \\
\hline HR processes are highly optimized & Mean $=3,27$ \\
\hline The crew's willigness to change is high & Mean $=2,88$ \\
\hline $\begin{array}{r}\text { The company is seen as attractive by the } \\
\text { applicants }\end{array}$ & Mean $=2,75$ \\
\hline
\end{tabular}

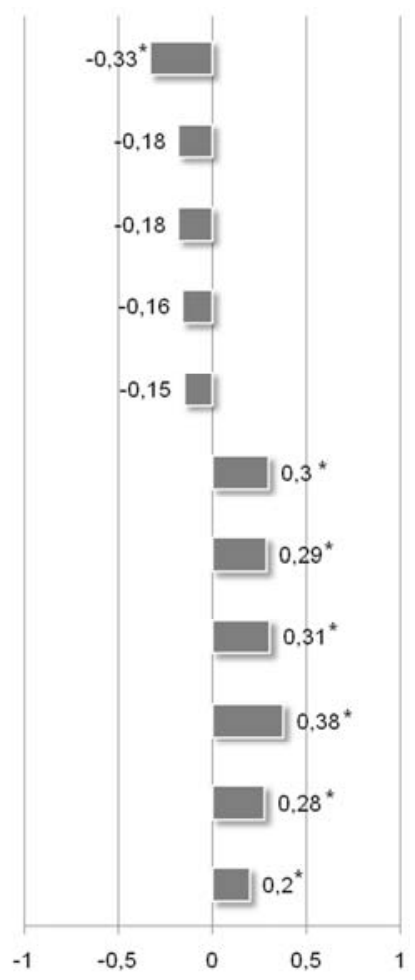

Figure 3. Respondents' assessment of the success of talent management in their organizations.

\section{Results}

The mean, standard deviations and Cronbach's alpha to measure the internal consistency of the main variables used in the study are presented in table 1a. 
Table 1a. Overview of main indices, variables and items.

\begin{tabular}{|c|c|c|c|c|c|}
\hline & Variable code & Mean & $\begin{array}{l}\text { Standard } \\
\text { deviation }\end{array}$ & Range & $\begin{array}{l}\text { Cronbach's } \\
\text { alpha }\end{array}$ \\
\hline \multicolumn{6}{|l|}{ Importance of Talent Management } \\
\hline $\begin{array}{l}\text { How do you rank the significance of talent management ranked in your } \\
\text { organization? }\end{array}$ & stew_tm & 4.01626 & .8296132 & $1-5$ & 0,63 \\
\hline Has the significance changed during the (current) crisis & delt_stew_tm & 1.98374 & .9494065 & $1-3$ & \\
\hline Is there a position/department dealing dealing mainly with talent management? & pos_tm & .8016529 & .400413 & $1-2$ & \\
\hline Is there an explicit talent strategy? & strat_tm & .557377 & .4987452 & $1-2$ & \\
\hline Do you use an IT tool? & itunt_tm & .3801653 & .4874457 & $1-2$ & \\
\hline \multicolumn{6}{|l|}{ Target groups } \\
\hline Top management & zielg_tm_tm & .5645161 & .4978316 & $0-1$ & \\
\hline Senior management & zielg_tm_sm & 6854839 & .4662065 & $0-1$ & \\
\hline Other employees with management responsibility & zielg_tm $\sim \mathrm{mfv}$ & .8790323 & .3274127 & $0-1$ & \\
\hline Other employees without management responsibility & zielg_tm ofv & .7016129 & .4594065 & $0-1$ & \\
\hline Tool design (HR) & beteilausa $\sim 0$ & .9435484 & .231728 & $0-1$ & \\
\hline Process execution (HR) & beteildurc $\sim 0$ & .9193548 & .273394 & $0-1$ & \\
\hline Process evaluation (HR) & beteileval o & .8951613 & .3075883 & $0-1$ & \\
\hline \multicolumn{6}{|l|}{ Commitment } \\
\hline HR Department & ant_tm_perso & .7790598 & .2584135 & $1-3$ & \\
\hline Executives & ant_tm_fk & .5150862 & .2705244 & $1-3$ & \\
\hline Top Management & ant_tm_tm & .5884615 & .3275026 & $1-3$ & \\
\hline \multicolumn{6}{|l|}{ Contentedness with talent management instruments in use (leadership) } \\
\hline Recruiting & zufuntl_tm_rec & 1.522936 & .554382 & $1-3$ & 0,51 \\
\hline Performance management & zufuntl_tm_per & 1.536364 & .5695205 & $1-3$ & \\
\hline Compensation management & zufuntl_tm_comp & 1.657407 & .5984722 & $1-3$ & \\
\hline Skill and competency management & zufuntl_tm_skm & 1.719626 & .5954924 & $1-3$ & \\
\hline Succession management & Zufuntl_tm_lnp & 1.880734 & .662833 & $1-3$ & \\
\hline \multicolumn{6}{|l|}{ Contentedness with talent management instruments in use (employees) } \\
\hline Recruiting & zufmit_tm_rec & 1.59633 & .5291374 & $1-3$ & $44 \%$ \\
\hline Skill and competency management & zufmit_tm_skm & 1.925234 & .508437 & $1-3$ & \\
\hline Succession management & Zufmit_tm_lnp & 2.192661 & .5177777 & $1-3$ & \\
\hline
\end{tabular}

Importance of Talent Management

Target Group

Roles of Talent Management

Commitment Roles

Contentedness with instruments (leadership and employees)

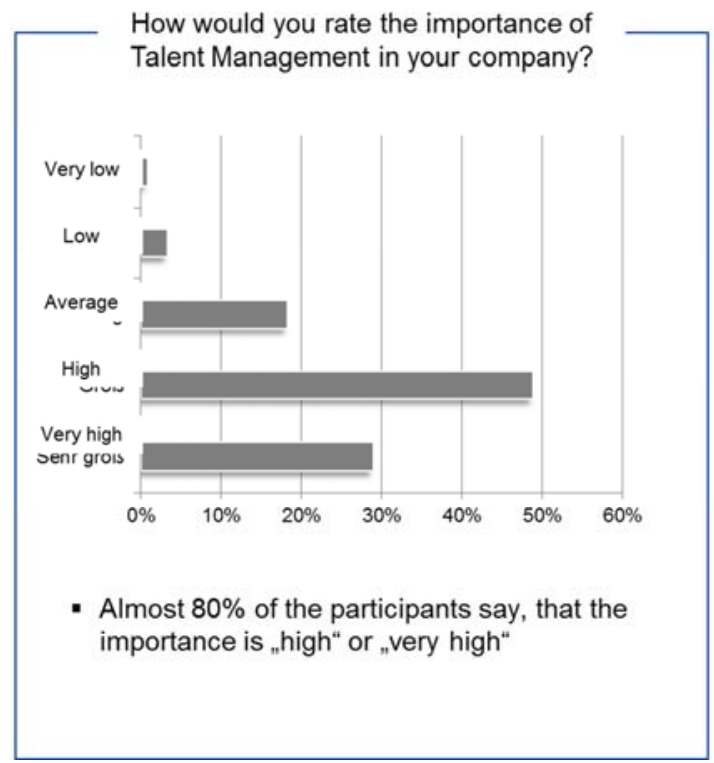

How did the importance of Talent Management change during the economic crisis?

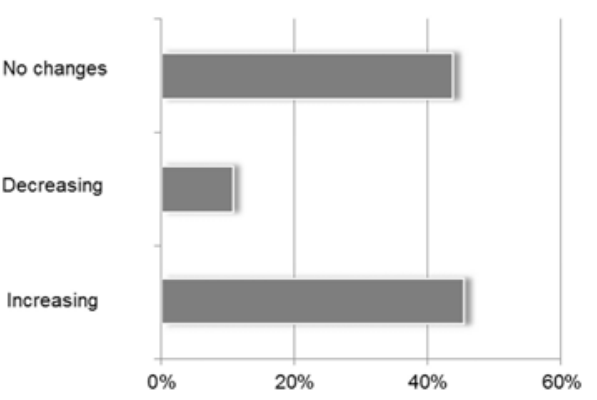

- $90 \%$ say that there is increasing or constant importance of Talent Management

Figure 4. Respondents' general evaluation of the importance of talent management. 
The majority of respondents, (almost 80 percent) describe the importance of talent management in their organizations as "big" or "very big". Asked for any changes as part of the 2009 financial crisis, 90 percent of the interviewees claim a rising or at least constant importance of talent management.

Despite the generally high perceived importance of talent management it surprises that a suitable infrastructure is often relatively weak. It appears that talent management is a topic whose importance is recognized on the abstract level but is (perhaps due to its complexness) hardly addressed on the concrete level. Everybody knows and agrees that it is important to care for talents, but there is an obvious lack of real strategies and knowledge of concrete facts - it appears that HR managers are kind of flying blind in this field. For example, measuring and tracking of results takes place only in half of the participating organizations and there are very few established metrics indicating the success of talent management activities. Also, in almost two thirds of the enterprises surveyed, talent management is carried out without an integrated IT solution facilitating the interaction between managers, HR and employees. In addition, most IT tools used are self-developed and therefore don't take advantage of external best practice. Not surprisingly, external benchmarking is the exception.

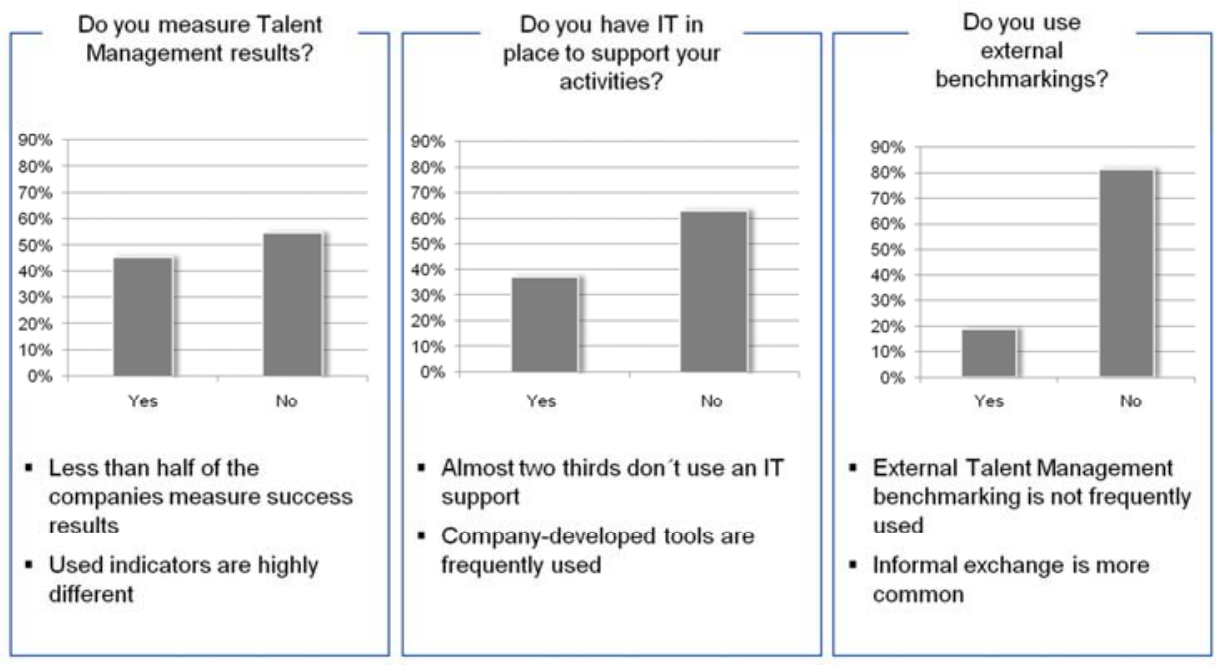

Figure 5. Results measurement, IT support and external benchmarking in talent management.

After all, in $80 \%$ of the participating organizations there exists an HR section predominately involved with talent management, whereas only $55 \%$ have an explicit talent management strategy.

Study participants were asked which talent management instruments are applied in their organizations and for which different target groups. $90 \%$ of the participants indicate that talent management refers to mid-level executives and in $70 \%$ to senior management. In $70 \%$ of the participating organizations employees without managerial responsibilities are a target group. However, filtering for organizational size shows that large-scale organizations (with more than 20,000 employees) often restrict their talent management to middle and upper executives; thus talent management is often not a comprehensive process.

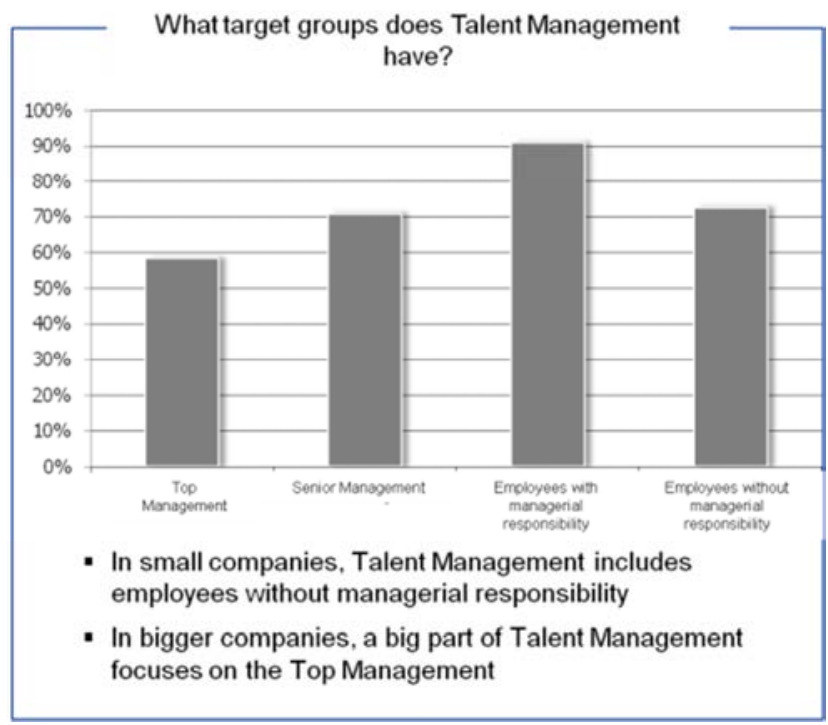

Figure 6. Target groups of talent management. 
As for the distribution of tasks, a very clear picture arises: while HR is evenly involved in all aspects of talent management from concept to evaluation of tasks, executives are expected to take the lead in implementation. Despite this high responsibility, executives' commitment to perform these tasks is often too low, which appears to be one of the main challenges of successful talent management. Despite the great importance attached to talent management in general, there appears to be a significant lack of awareness and commitment among executives and thus a lack of support for the implementation of talent management activities.
Asked about whether the intended roles are executed with full commitment, the executives clearly score lowest in the opinion of the participants who obviously have identified a lack of responsibility. Only in little more than half of the organizations is this role executed with full conviction as perceived by the participants. This is especially significant in light of the finding that the organizations in which executives do fill their roles with high levels of commitment have a significantly higher likelihood of being a successful organization. This means, the executives themselves represent a highly significant success factor for talent management.
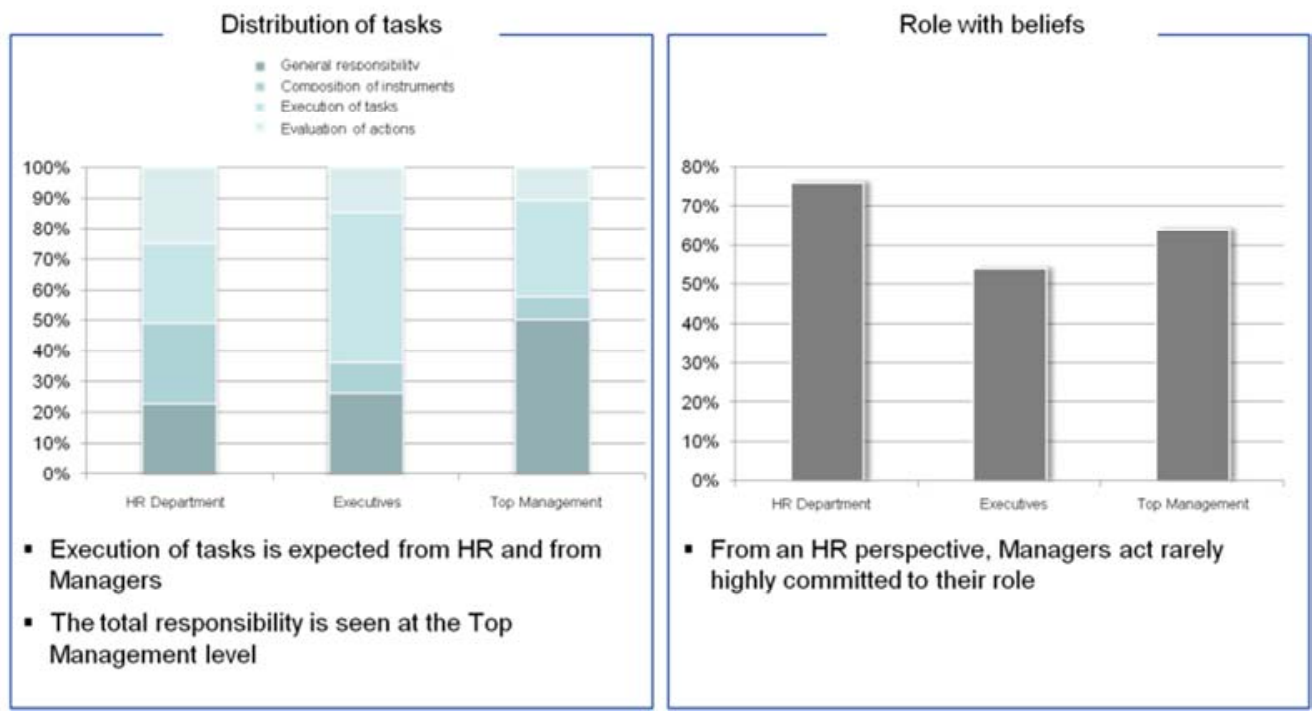

Figure 7. Distribution of talent management tasks, and commitment.

Overall, the organizations which are able to set up successful talent management processes create more value from "human capital" available to them, because they can identify and allocate talents better, must recruit less externally and lose less talents. A lot speaks for the fact that such investments are exceptionally profitable.

Finally, satisfaction levels with talent management instruments are higher among executives compared to employees indicating that talent management is understood as investment however with limited payoff so far.

Table 1b. Specific talent management instruments.

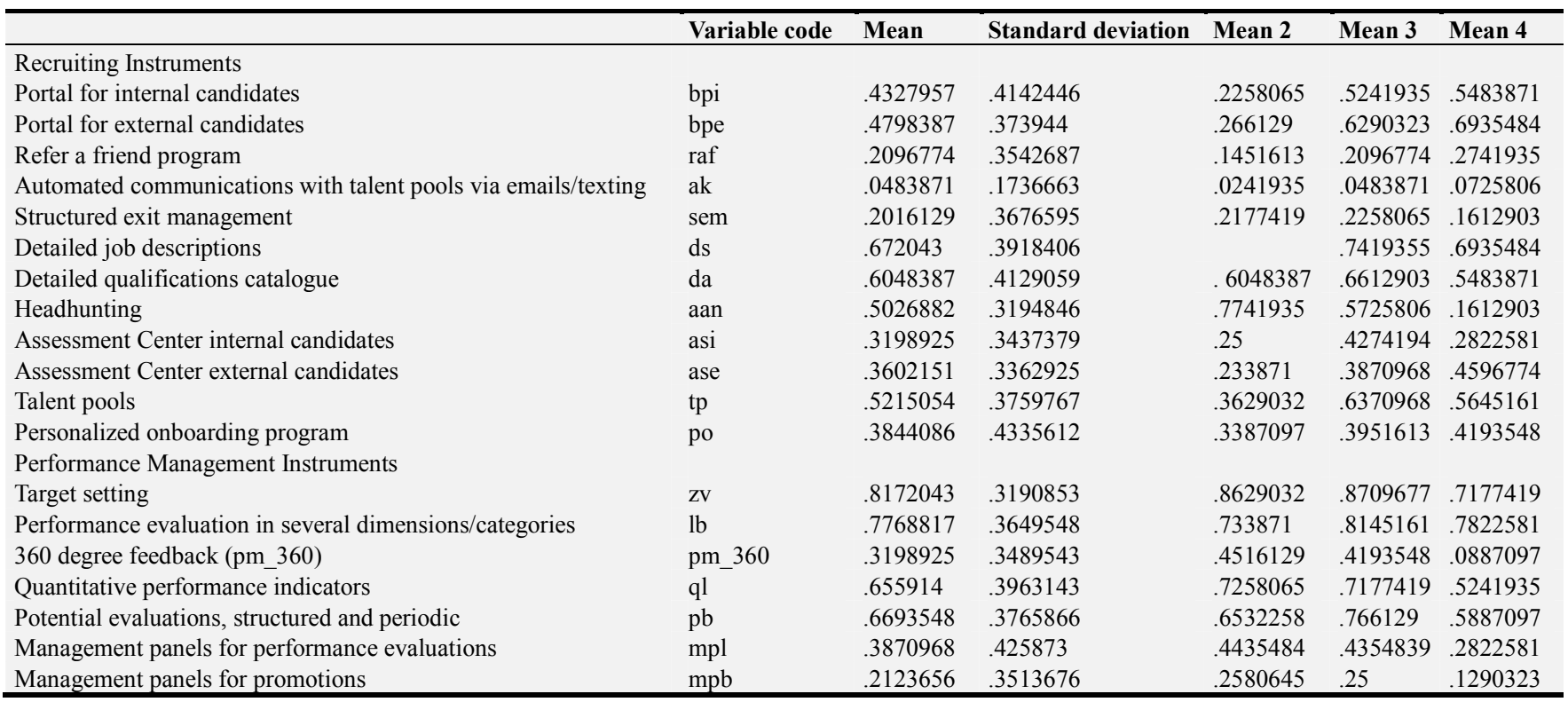




\begin{tabular}{|c|c|c|c|c|c|c|}
\hline & Variable code & Mean & Standard deviation & Mean 2 & Mean 3 & Mean 4 \\
\hline Recommended distribution of performance categories & evl & .2473118 & .3984409 & .25 & .266129 & .2258065 \\
\hline Forced distribution & $\mathrm{fd}$ & .0564516 & .2113397 & .0645161 & .0483871 & .0564516 \\
\hline \multicolumn{7}{|l|}{ Compensation Management Instruments } \\
\hline Variable pay components in general & vgka & .7741936 & .3361625 & .8709677 & .8225806 & .6290323 \\
\hline Variable pay components on the basis of team performance & vgkt & .3682796 & .3960477 & .3387097 & .3870968 & .3790323 \\
\hline Variable pay components on the basis of individual performance & vgki & 6827957 & .3750455 & .75 & .7580645 & .5403226 \\
\hline Optional unpaid vacation sabbatical & $\mathrm{uu}$ & .2553763 & .3967093 & .1854839 & .2741935 & .3064516 \\
\hline Variable pay components on the basis of company performance & vgku & .6827957 & .3701969 & .8387097 & .7016129 & .5080645 \\
\hline \multicolumn{7}{|l|}{ Skill and competency Instruments } \\
\hline Personalized development plans & pep & 6129032 & .4085515 & .5322581 & .7016129 & .6048387 \\
\hline Employee portal for training and continuing education & $\mathrm{mp}$ & .5322581 & .4576349 & .4354839 & .5725806 & .5887097 \\
\hline Competency model & $\mathrm{km}$ & .6155914 & .4121996 & .5887097 & 6935484 & .5645161 \\
\hline Management training, external & $\mathrm{mt}$ & .6424731 & .3213943 & .8145161 & .8064516 & .3064516 \\
\hline \multicolumn{7}{|l|}{ Succession planning Instruments } \\
\hline Alternative career paths & aak & .3037634 & .355654 & .1612903 & .3306452 & .4193548 \\
\hline Mid and long-term succession plans & mnlp & .5430108 & .3332459 & .7580645 & .6612903 & .2096774 \\
\hline Domino lists & dl & .1129032 & .2546305 & .1532258 & .1451613 & .0403226 \\
\hline Requirements / potential alignments & $a b p$ & .3145161 & .4016732 & .3145161 & .3870968 & .2419355 \\
\hline
\end{tabular}

Mean $=$ All employees

Mean 2=Top and senior management

Mean 3=Middle management

Mean 4=Employees without management responsibility

Table 1c. Quality of talent management processes.

\begin{tabular}{|c|c|c|c|c|c|}
\hline & $\begin{array}{l}\text { Variable } \\
\text { code }\end{array}$ & Mean & $\begin{array}{l}\text { Standard } \\
\text { deviation }\end{array}$ & Range & $\begin{array}{l}\text { Cronbach's } \\
\text { alpha }\end{array}$ \\
\hline Recruiting & & & & & 0.53 \\
\hline Employees outside of recruiting regularly get involved in recruiting processes & stelbes_1 & 4,137615 & 1.150426 & $1-5$ & \\
\hline Even young very talented employees can obtain management positions in our company & stelbes_2 & 3.907407 & .9020956 & $1-5$ & \\
\hline $\begin{array}{l}\text { In our company, we value working experience very highly when filling important managing } \\
\text { positions }\end{array}$ & stelbes_3 & 3.648148 & .7771842 & $1-5$ & \\
\hline There are always high numbers of internal applications when open positions are posted & stelbes_4 & 3.141509 & .9898406 & $1-5$ & \\
\hline $\begin{array}{l}\text { Internal jobs are frequently filled with applicants who have been informally appointed in } \\
\text { advance }\end{array}$ & stelbes_5 & 3.168224 & 1.032363 & $1-5$ & \\
\hline $\begin{array}{l}\text { Often those internal candidates are successful who prior had not been considered for this } \\
\text { role }\end{array}$ & stelbes_6 & 2.783019 & .8508228 & $1-5$ & \\
\hline There are frequent cross divisional and cross functional transfers & stelbes_7 & 2.849057 & 1.0216 & 1.5 & \\
\hline $\begin{array}{l}\text { The capabilities of available internal candidates often influence the job design for open } \\
\text { positions }\end{array}$ & stelbes_8 & 2.669811 & 1.002109 & 1.5 & \\
\hline Performance management & & & & & 0.60 \\
\hline In case your organization has a competency model, is it used regularly and comprehensively & kommod_1 & 3.294872 & 1.117848 & $1-5$ & \\
\hline The competency model is regularly updated & kommod_2 & 3.320513 & 1.178747 & $1-5$ & \\
\hline $\begin{array}{l}\text { The content of personnel development plans is mostly influenced by the employee } \\
\text { himself/herself }\end{array}$ & einfent_ms & 3.66 & .8192137 & $1-5$ & \\
\hline The content of personnel development plans is mostly influenced by the direct superior & einfent_dv & 4 & .6963106 & $2-5$ & \\
\hline The content of personnel development plans is mostly influenced by HR & einfent_pb & 3.16 & 1.032013 & $1-5$ & \\
\hline The potential of an employee finds strong consideration in the career planning process & berueck_1 & 4.11215 & .7180569 & $2-5$ & \\
\hline Compensation management & & & & & 0.65 \\
\hline The compensation package can be tailored individually based on employee preferences & comman_1 & 2.489796 & 1.076888 & $1-5$ & \\
\hline More and more employees take advantage of this service & comman_2 & 2.206522 & .9438994 & $1-5$ & \\
\hline $\begin{array}{l}\text { Employees with high potential are being compensated significantly higher than other } \\
\text { employees }\end{array}$ & comman_3 & 2.948454 & 1.083697 & $1-5$ & \\
\hline Skill and competency management & & & & & 0.65 \\
\hline The career development plans reflect the realistic professional objectives. & sukman_1 & 3.602041 & .74252 & $1-5$ & \\
\hline Training and advanced training plans are seen as self-controllable by our employees. & sukman_2 & 3.336735 & .8727711 & $1-5$ & \\
\hline Our Skill and Competency Management considers the employees' personality. & sukman_3 & 3.520408 & .9441037 & $1-5$ & \\
\hline Development plans are being implemented with high probability & sukman_4 & 3.494845 & .7789377 & $2-5$ & \\
\hline The implementation of personal development plans is regularly supervised & sukman_5 & 3.272727 & 1.03823 & $1-5$ & \\
\hline Succession management & & & & & 0.48 \\
\hline Cross-division or functional career paths are more often initiated through the employer than & initfuwe & 3.273585 & 1.046837 & $1-5$ & \\
\hline
\end{tabular}




\begin{tabular}{lllll}
\hline & $\begin{array}{l}\text { Variable } \\
\text { code }\end{array}$ & Mean & $\begin{array}{l}\text { Standard } \\
\text { deviation }\end{array}$ & $\begin{array}{c}\text { Range } \\
\text { alpha }\end{array}$ \\
\hline $\begin{array}{l}\text { individual employees } \\
\text { Global mobility assignments are more often initiated through the employer than individual } \\
\text { employees }\end{array}$ & initausent & 2.095745 & .951164 & $1-5$ \\
$\begin{array}{l}\text { The employees' personal objectives are strongly considered for their career development. } \\
\text { The overall personality of an employee finds recognition in their career development }\end{array}$ & $\begin{array}{l}\text { berueck_2 } \\
\text { berueck_3 }\end{array}$ & 3.682243 & .7721342 & $1-5$ \\
$\begin{array}{l}\text { The individual situation of each employee is considered when designing time and content of } \\
\text { their job }\end{array}$ & berueck_4 3.27619 & .7187932 & $2-5$ \\
$\begin{array}{l}\text { The company enables personalized career paths based on the employees' interest and life } \\
\text { objectives }\end{array}$ & nukman_1 3.04902 & 1.137806 & $1-5$ \\
$\begin{array}{l}\text { Maternity leave, sabbaticals and other leave of absent is being considered in career } \\
\text { management }\end{array}$ & nukman_2 3.213592 & 1.16863 & $1-5$ \\
\begin{tabular}{l} 
The use of flexible time-off policy obstructs a structured succession management \\
\hline
\end{tabular} & nukman_3 2.535354 & 1.081506 & $1-5$ \\
\hline
\end{tabular}

Quality of Talent Management processes and procedures

Table $1 \mathrm{~b}$ and $1 \mathrm{c}$ provide an overview over the use of specific instruments sorted by life cycle, as well as processes and procedures respectively. In order to get a first overview of how widespread specific talent management instruments are used in practice, the participants were asked to mark in a closed list of 36 instruments the ones used in their organization as well as their target population, which shows

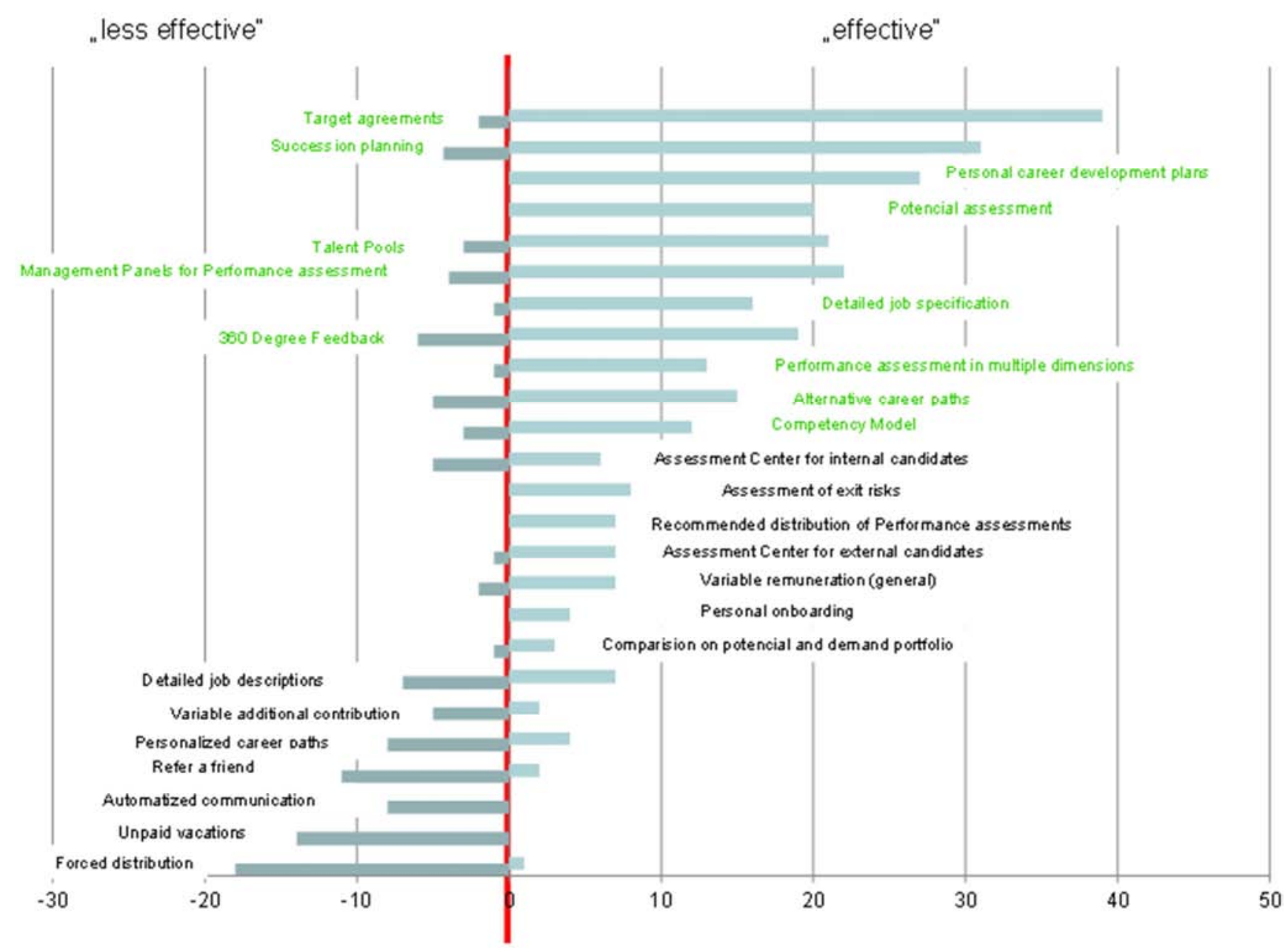

Figure 8. Assessment of instruments by talent managers as less or more effective.

As an example, goal settings, succession planning, personalized development plans and talent pools are assessed almost unanimously as effective due to their large differences in the use of specific instruments across all target groups. As a result, lists of instruments could be distilled which are almost unanimously perceived as effective, others which had been assessed as rather "neutral", other which are rather polarizing and also instruments which have been classified by the majority of participants as more or less ineffective. 
distribution', a performance management process as carried out at the American group General Electric, has been assessed nearly unanimously negatively by the respondents. Generally, it appears that the most widespread instruments are not necessarily the most effective. In contrast, quite often relatively little use is made of the most effective instruments (i.e. personalized career paths, exit management, automated communication with talent pools).

By separately analyzing the talent portfolio of companies with high subjective success of talent management together with companies in which this is not the case, it was possible to identify both instruments and specific procedures which describe successful companies as opposed to less successful companies. While causalities cannot clearly be determined, this analysis revealed some interesting patterns.

For example, one of the success factors appears to be the use of instruments to systematically measure the employee potential and to identify special talents on the basis of this information. Our analysis shows that successful companies use systematic potential appraisals significantly more often than less successful ones. Besides, it seems important to trust not only the judgment of the direct executive, but to confirm this assessment clear and understandably by others. Often internal assessment centers are used for this. Surprisingly, management panels in which several executives discuss together potential and performance evaluations or promotional decisions are seldom used in the participating companies. However, it appears that companies with overall successful talent management processes use such performance panels significantly more frequently.

A key issue in the identification of talents in companies is that executives tend not to differentiate enough when assessing potential due to positivity bias and dissonance reduction. In many companies, frequently very different performance levels find application in different functional areas. However, the development of uniform assessment standards is important to be able to compare talents across functional areas. It appears that successful companies use significantly more often recommended performance and potential ratings to support executives applying the same differentiation criteria. However, companies using the stricter 'forced distribution' tend to assess their talent management as less successful. Talent managers seem to share the skepticism cited towards the forced distribution systems. In contrast, talent pools are often the central instrument to promote a group of especially gifted employees. They are being used in $72 \%$ of the less successful companies, but in $86 \%$ of the successful ones.

Nevertheless, the study also points out that successful enterprises handle the subject of talent management much more openly and produce more transparency than less successful companies. They communicate the existence of talent pools more openly and inform the employees about their talent pool affiliation. Remarkably, successful enterprises also significantly more often permit a selfapplication process for employees for admission to talent pools, which is also in line with findings in fairness research: Fairness and openness constitute important motivational factors for employees.

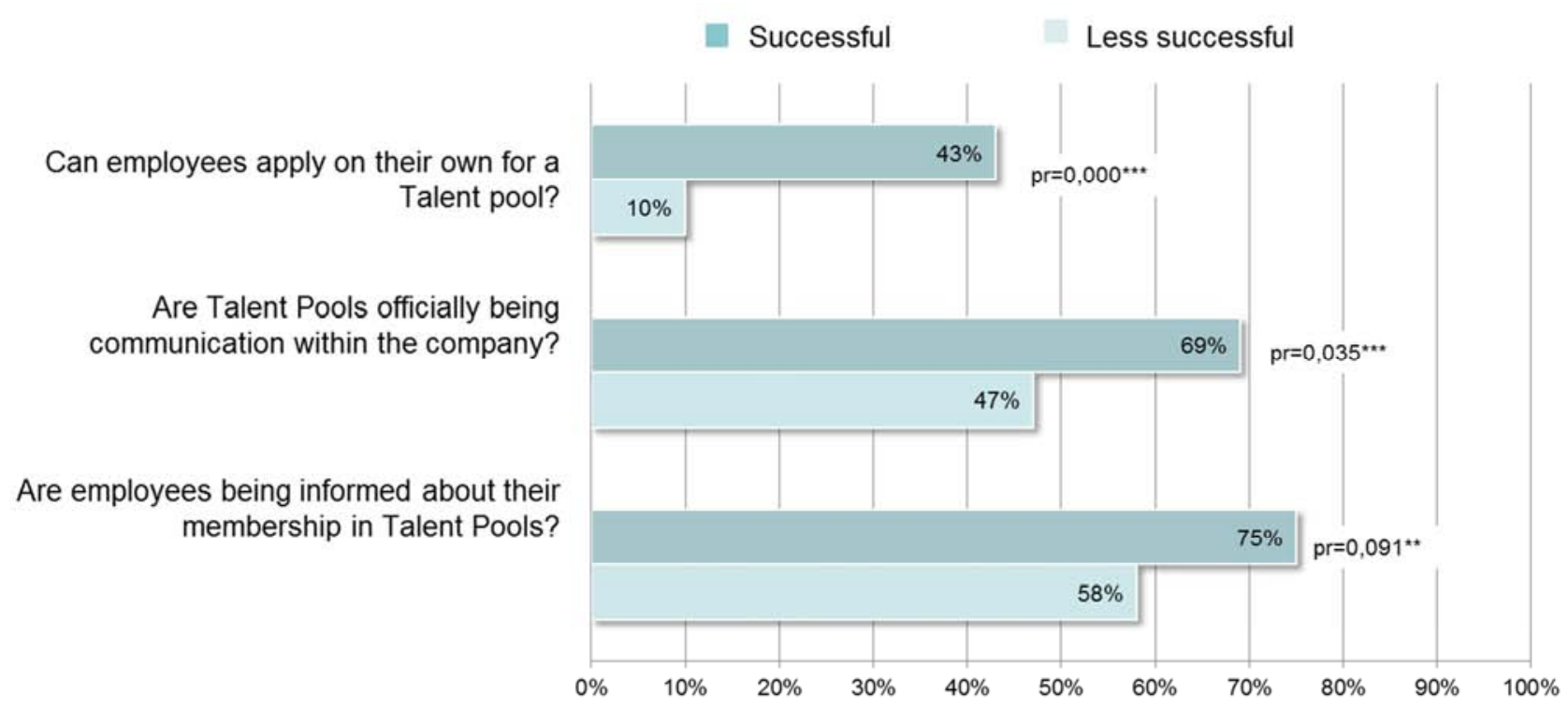

Figure 9. Openness and transparency about talent pools.

In addition, the analysis of effectiveness of a balanced set of talent processes underlines the importance of a functioning clear internal job market also from an employee's view. This is found, for example, based on the significantly higher approval rate in successful companies for statements such as 'there are many internal applicants on posted internal positions' and also that 'employees initially not considered for a position through the regular talent processes' can be successful in open positions. 

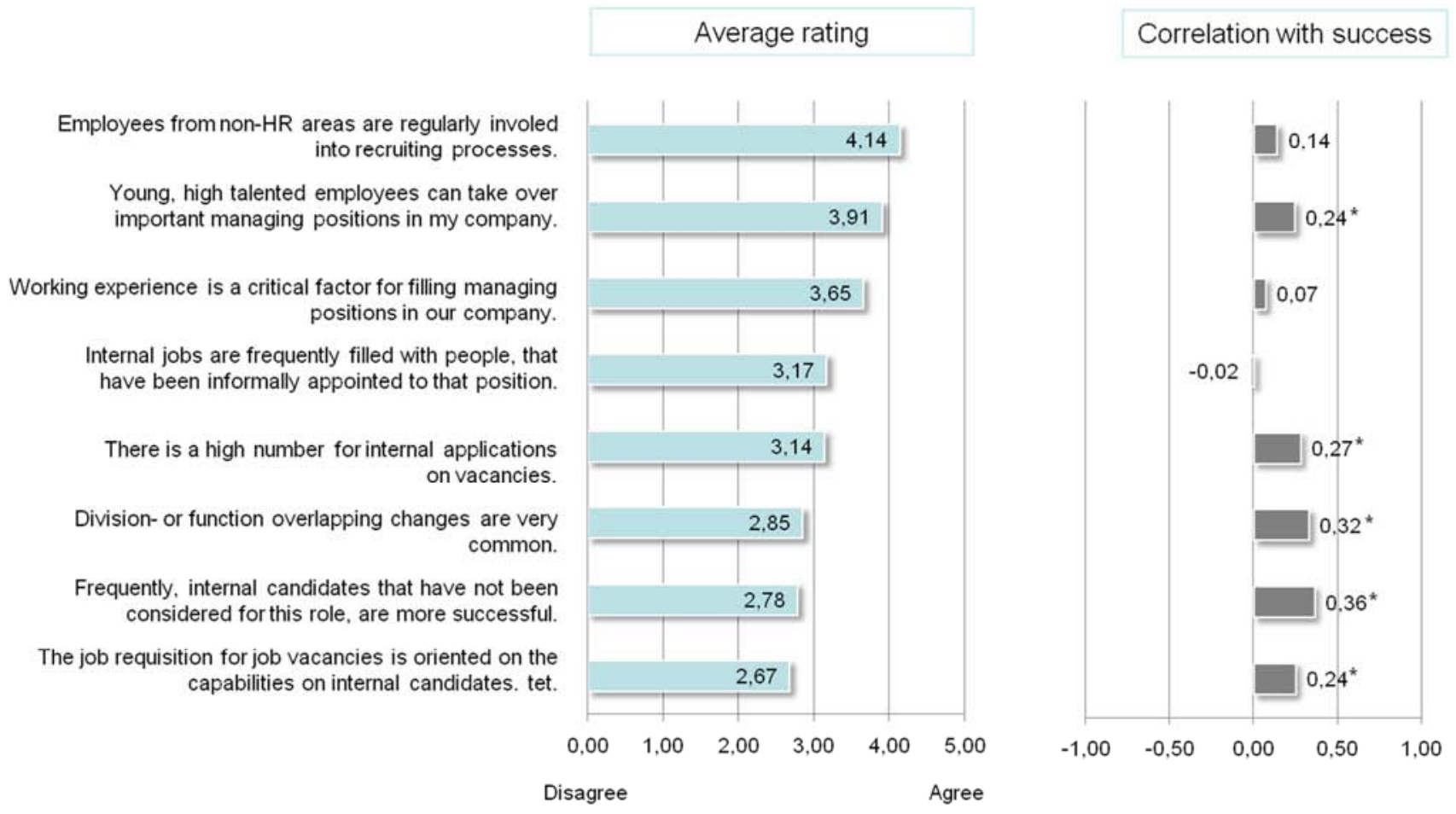

Figure 10. Internal recruiting.

Success factor 'Alternative career paths'

In the area of career and succession planning, the traditional nuclear area of talent management, the most effective instruments are not necessarily the widespread ones. While offers of alternative career paths (for example, an expert's career) as well as personalized career paths likewise seem to be signs for successful talent management $(\mathrm{pr}=0.000$, $\mathrm{pr}=0.002$ ), these offers still are rather the exception. The chart below summarizes the significance levels of specific instruments linked to career and succession planning in indicating successful vs. less successful companies:

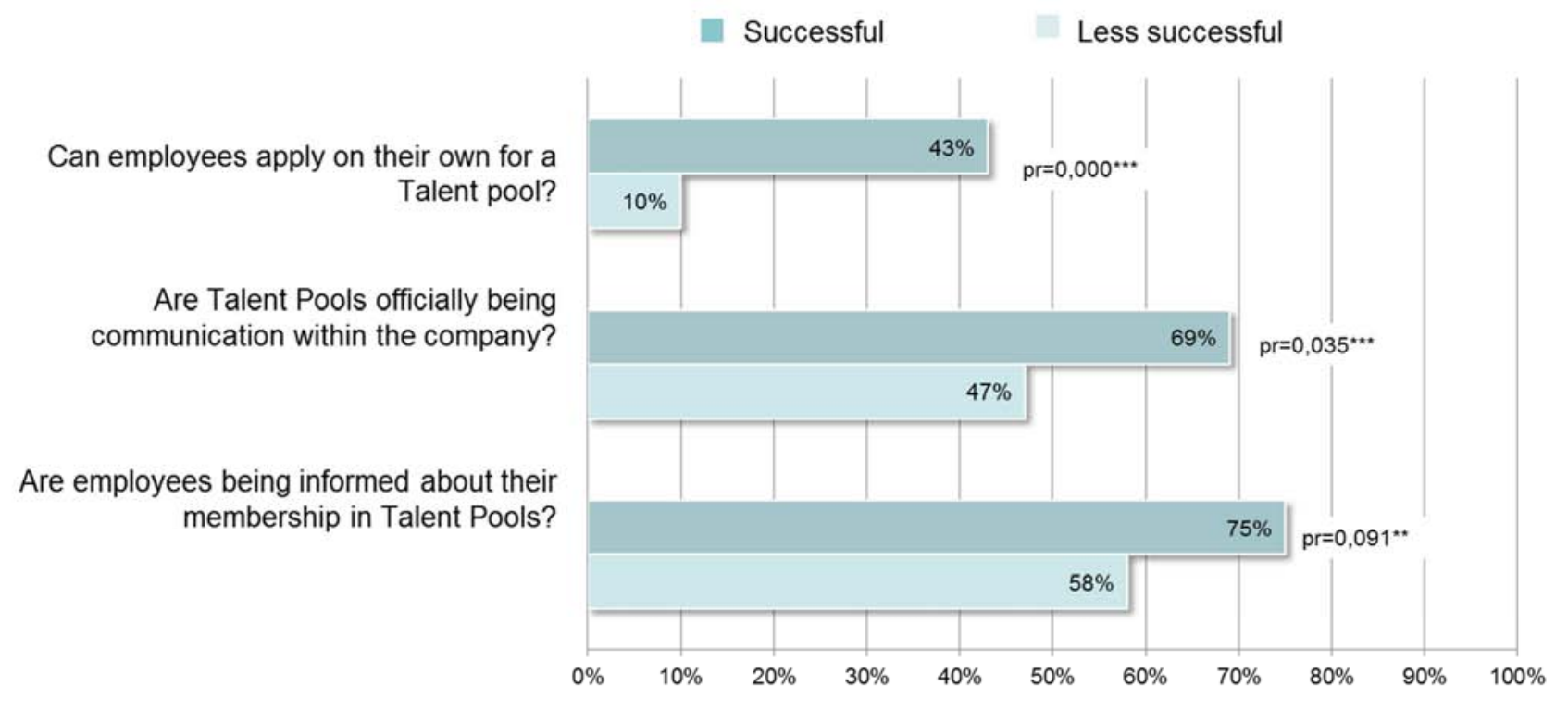

Figure 11. Talent pools.

Success factor 'Management of separations'

Surprisingly, in times of a financial crisis, during which many companies need to adjust staff levels, the importance of good separation management seems to be underestimated by many organizations. This includes the assessment of fluctuation risks as well as a structured exit management serving to learn from fluctuation and to protect the remaining key talents. 


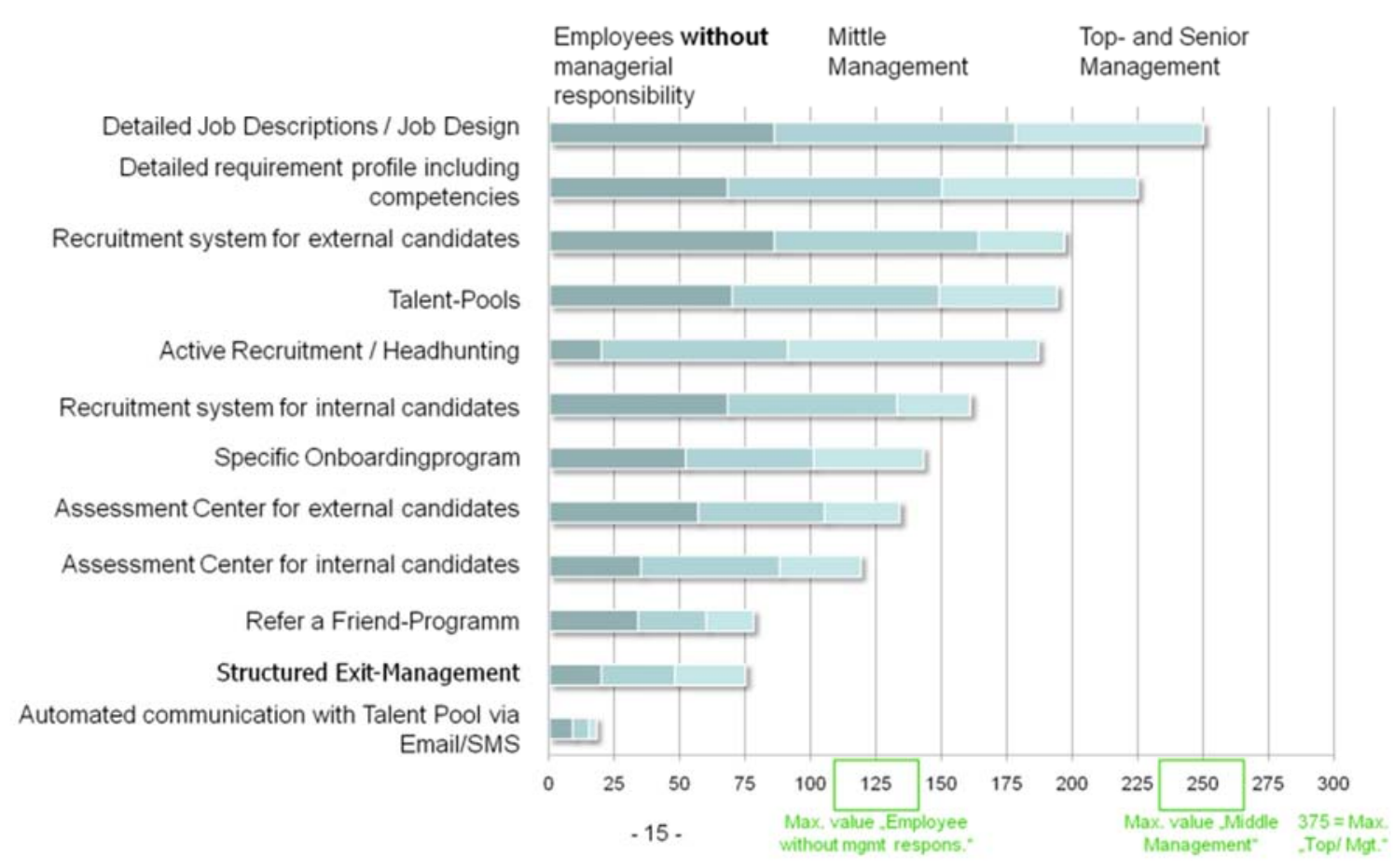

Figure 12. Distribution of recruiting tools in target groups.

Success factor 'Incentive management'

The structured measurement of performance and in particular the variable reimbursement of team achievements also appears success-critical for talent management. In this regard, the study points in particular to the importance of team bonus payments, which are used by more successful enterprises significantly more often than in the comparative group. Team bonus systems can generate a positive influence on the solidarity, the willingness to co-operate and the identification with the success of the organization. In such a climate talent management can better function, because, for example, the acceptance of performance differentiation rises if the organization as a whole benefits.
In order to test the hypothesis about success factors of talent management, separate hierarchical regression analyses were carried out for each talent management area sorted by life cycle. Tables 3 and 4 show the results for talent management instruments and processes respectively. Table 3 confirms the negative effect of forced distribution, as well as the positive effect of variable pay, personalized career paths and the probability assessment of turnover intention. Table 4 clearly confirms the expected direction and significance levels for openness and transparency of the recruiting processes, inclusion of potential, as well as self-control.

Table 2 shows the correlations among the groups of talent management instruments and processes sorted by life cycle.

Table 2. Means, standard deviations and correlations for all variables.

\begin{tabular}{|c|c|c|c|c|c|}
\hline Variables & Mean & $\begin{array}{l}\text { Standard } \\
\text { deviation }\end{array}$ & $\begin{array}{l}\text { Recruiting } \\
\text { instruments }\end{array}$ & $\begin{array}{l}\text { Performance } \\
\text { instruments }\end{array}$ & $\begin{array}{l}\text { Compensation } \\
\text { instruments }\end{array}$ \\
\hline Recruiting instruments & .4301002 & .1686412 & 1.0000 & & \\
\hline Performance instruments & .5227687 & .1787906 & 0.5631 & 1.0000 & \\
\hline Compensation instruments & .5591985 & .1963842 & 0.3286 & 0.3267 & 1.0000 \\
\hline Skill \& competency instruments & .7226776 & .2133948 & 0.5770 & 0.5761 & 0.4793 \\
\hline Succession and career planning & .3205829 & .209446 & 0.4808 & 0.5821 & 0.3476 \\
\hline Importance talent management & 4.065574 & .7498634 & 0.4377 & 0.4491 & 0.0424 \\
\hline Delta importance & 2 & .9486833 & -0.1881 & -0.1710 & -0.0398 \\
\hline Talent department (separate) & .7868852 & .4129065 & 0.2878 & 0.1964 & -0.0359 \\
\hline Talent strategy & .6065574 & .4925677 & 0.1176 & 0.3137 & -0.0328 \\
\hline Success measurement & .442623 & .500819 & 0.3752 & 0.3509 & -0.0261 \\
\hline IT support & .442623 & .500819 & 0.1477 & 0.2130 & -0.1014 \\
\hline External benchmarking & .1967213 & .4008188 & 0.4363 & 0.1605 & -0.1269 \\
\hline Recruiting processes & 3.245902 & .4908213 & 0.3234 & 0.3758 & 0.2979 \\
\hline Performance mgmt. processes & 3.778689 & .5684378 & 0.2784 & 0.2038 & 0.2707 \\
\hline Compensation mgmt. processes & 2.807377 & .6667606 & 0.4557 & 0.4471 & 0.2176 \\
\hline Skill and Competency mgmt. proc. & 4.377049 & .7522507 & 0.1131 & 0.2552 & 0.2413 \\
\hline Succession mgmt. processes & 3.065574 & .7066344 & 0.1233 & 0.1004 & 0.1917 \\
\hline
\end{tabular}


Table 2. Continued.

\begin{tabular}{|c|c|c|c|c|c|}
\hline Variables & $\begin{array}{l}\text { Skill and Competency } \\
\text { instruments }\end{array}$ & $\begin{array}{l}\text { Succession and } \\
\text { career planning }\end{array}$ & $\begin{array}{l}\text { Importance talent } \\
\text { management }\end{array}$ & $\begin{array}{l}\text { Delta } \\
\text { importance }\end{array}$ & $\begin{array}{l}\text { Talent department } \\
\text { (separate) }\end{array}$ \\
\hline \multicolumn{6}{|l|}{ Recruiting instruments } \\
\hline Performance instruments & & & & & \\
\hline Compensation instruments & & & & & \\
\hline Skill \& competency instruments & 1.0000 & & & & \\
\hline Succession and career planning & 0.5307 & 1.0000 & & & \\
\hline Importance talent management & 0.2284 & 0.2589 & 1.0000 & & \\
\hline Delta importance & -0.1990 & -0.2423 & -0.1171 & 1.0000 & \\
\hline Talent department (separate) & 0.2481 & 0.1287 & 0.4227 & -0.2127 & 1.0000 \\
\hline Talent strategy & 0.1471 & 0.2108 & 0.3418 & -0.0713 & 0.4003 \\
\hline Success measurement & 0.1670 & 0.4254 & 0.3652 & -0.1052 & 0.3026 \\
\hline IT support & 0.1930 & 0.0194 & 0.3208 & 0.2105 & 0.2220 \\
\hline External benchmarking & 0.2750 & 0.4054 & 0.1782 & -0.1315 & 0.2575 \\
\hline Recruiting processes & 0.3304 & 0.4518 & 0.2660 & -0.1534 & 0.0397 \\
\hline Performance mgmt. processes & 0.3358 & 0.3492 & 0.2888 & -0.1854 & 0.0620 \\
\hline Compensation mgmt. processes & 0.5017 & 0.4031 & 0.2840 & -0.2635 & 0.1965 \\
\hline Skill and Competency mgmt. proc. & 0.3205 & 0.3234 & 0.3248 & -0.3036 & 0.1289 \\
\hline Succession mgmt. processes & 0.2239 & 0.1913 & 0.0442 & -0.0994 & 0.0677 \\
\hline
\end{tabular}

Table 2. Continued.

\begin{tabular}{|c|c|c|c|c|c|}
\hline Variables & Talent strategy & $\begin{array}{l}\text { Success } \\
\text { measurement }\end{array}$ & IT support & $\begin{array}{l}\text { External } \\
\text { benchmarking }\end{array}$ & $\begin{array}{l}\text { Recruiting } \\
\text { processes }\end{array}$ \\
\hline \multicolumn{6}{|l|}{ Recruiting instruments } \\
\hline \multicolumn{6}{|l|}{ Compensation instruments } \\
\hline \multicolumn{6}{|l|}{ Skill \& competency instruments } \\
\hline \multicolumn{6}{|l|}{ Importance talent management } \\
\hline \multicolumn{5}{|l|}{ Delta importance } & Talent department (separate) \\
\hline Talent strategy & 1.0000 & & & & \\
\hline Success measurement & 0.2448 & 1.0000 & & & \\
\hline IT support & 0.2448 & 0.2026 & 1.0000 & & \\
\hline External benchmarking & 0.2297 & 0.2232 & 0.2232 & 1.0000 & \\
\hline Recruiting processes & 0.2788 & 0.2472 & -0.0821 & 0.1010 & 1.0000 \\
\hline Performance mgmt. processes & 0.1005 & 0.1742 & 0.1596 & 0.2308 & 0.3114 \\
\hline Compensation mgmt. processes & 0.1333 & 0.2970 & 0.1473 & 0.2221 & 0.2581 \\
\hline Skill and Competency mgmt. proc. & 0.0022 & 0.0805 & 0.1026 & -0.0014 & 0.2928 \\
\hline Succession mgmt. processes & 0.0594 & 0.0736 & -0.1462 & 0.0910 & 0.4562 \\
\hline
\end{tabular}

Table 2. Continued.

\begin{tabular}{|c|c|c|c|c|}
\hline Variables & $\begin{array}{l}\text { Performance mgmt. } \\
\text { processes }\end{array}$ & $\begin{array}{l}\text { Compensation } \\
\text { processes }\end{array}$ & $\begin{array}{l}\text { Skill and competency } \\
\text { mgmt. processes }\end{array}$ & $\begin{array}{l}\text { Succession mgmt } \\
\text { processes zation }\end{array}$ \\
\hline \multicolumn{5}{|l|}{ Recruiting instruments } \\
\hline \multicolumn{5}{|l|}{ Performance instruments } \\
\hline \multicolumn{5}{|l|}{ Compensation instruments } \\
\hline \multicolumn{5}{|l|}{ Skill \& competency instruments } \\
\hline \multicolumn{5}{|l|}{ Succession and career planning } \\
\hline \multicolumn{5}{|l|}{ Importance talent management } \\
\hline \multicolumn{5}{|l|}{ Delta importance } \\
\hline \multicolumn{5}{|l|}{ Talent department (separate) } \\
\hline \multicolumn{5}{|l|}{ Talent strategy } \\
\hline \multicolumn{5}{|l|}{ Success measurement } \\
\hline \multicolumn{5}{|l|}{ IT support } \\
\hline \multicolumn{5}{|l|}{ External benchmarking } \\
\hline \multicolumn{5}{|l|}{ Recruiting processes } \\
\hline Performance mgmt. processes & 1.0000 & & & \\
\hline Compensation mgmt. processes & 0.4518 & 1.0000 & & \\
\hline Skill and Competency mgmt. proc. & 0.6052 & 0.5356 & 1.0000 & \\
\hline Succession mgmt. processes & 0.3548 & 0.3073 & 0.2819 & 1.0000 \\
\hline
\end{tabular}


Jens Landwehr: The Use of Talent Management Instruments and Procedures in Germany: A Broad Explorative Study of Effectiveness and Success Factors

Table 3. Results of regression analysis: Specific talent management instruments (dependent variable: success of talent management).

\begin{tabular}{|c|c|c|c|c|c|}
\hline & \multirow[t]{2}{*}{ Variable code } & \multirow{2}{*}{\multicolumn{2}{|c|}{$\begin{array}{c}\text { Model 1a } \\
\mathbf{P}\end{array}$}} & \multicolumn{2}{|c|}{ Model 1b } \\
\hline & & & & Beta & $\mathbf{p}$ \\
\hline Talent Infrastructure & Index3481012 & 1.35284 & $0.000 * * *$ & 1.420249 & $0.000 * * *$ \\
\hline Size Dummy 1 & Groesse1 & -.2224479 & 0.328 & -.0333204 & 0.894 \\
\hline Size Dummy 2 & Groesse2 & .0265365 & 0.910 & -.011669 & 0.962 \\
\hline Size Dummy 3 & Groesse3 & .3768717 & 0.234 & .5978306 & $0.064^{*}$ \\
\hline Size Dummy 4 & Groesse3 & -.144085 & 0.648 & -.1423524 & 0.661 \\
\hline Industry Dummy 1 & BrancheECP & .4689061 & 0.353 & .4957256 & 0.316 \\
\hline Industry Dummy 1 & BrancheMFM & .4507686 & 0.379 & .5179958 & 0.307 \\
\hline Industry Dummy 2 & Branche ESP & .6841903 & 0.204 & .7514022 & 0.159 \\
\hline Industry Dummy 3 & BrancheDL & .6684645 & 0.179 & .6719543 & 0.172 \\
\hline Detailed job descriptions & ds & -.123951 & 0.628 & -.0842929 & 0.764 \\
\hline Detailed qualifications catalogue & da & .1804446 & 0.456 & .1840955 & 0.470 \\
\hline Portal for internal candidates & bpi & .1761951 & 0.506 & .668813 & 0.807 \\
\hline Portal for external candidates & bpe & -.5182974 & $0.079 *$ & -.5257731 & $0.076^{*}$ \\
\hline Headhunting & aan & -.4237579 & 0.159 & -.5216906 & $0.091 *$ \\
\hline Refer a friend program & raf & -.0136689 & 0.955 & -.1181005 & 0.659 \\
\hline Assessment Center internal candidates & asi & .3663592 & 0.203 & .4097124 & 0.150 \\
\hline Assessment Center external candidates & ase & -.2586388 & 0.386 & -.4017831 & 0.198 \\
\hline Personalized onboarding program & po & .1907678 & 0.355 & .3294601 & 0.128 \\
\hline Talent pools & tp & -.2362821 & 0.430 & -.3760893 & 0.224 \\
\hline Automated communications with talent pools via emails/texting & ak & .5617921 & 0.234 & .3082604 & 0.540 \\
\hline Structured exit management & sem & .3312138 & 0.175 & .3452505 & 0.216 \\
\hline Target setting & $\mathrm{zv}$ & & & 1.236023 & $0.008^{* * *}$ \\
\hline Quantitative performance indicators & $\mathrm{q} 1$ & & & .1058041 & 0.682 \\
\hline Performance evaluation in several dimensions/categories & $\mathrm{lb}$ & & & -.4134865 & 0.178 \\
\hline Potential evaluations, structured and periodic & $\mathrm{pb}$ & & & -.0001398 & 1.000 \\
\hline Management panels for performance evaluations & $\mathrm{mpl}$ & & & -.1096695 & 0.651 \\
\hline Management panels for promotions & $\mathrm{mpb}$ & & & .0312002 & 0.911 \\
\hline Recommended distribution of performance categories & evl & & & .3917538 & 0.113 \\
\hline Forced distribution & $\mathrm{fd}$ & & & -.7594503 & $0.083 *$ \\
\hline 360 degree feedback & pm_360 & & & .1396283 & 0.636 \\
\hline Variable pay components in general & vgka & & & & \\
\hline Variable pay components on the basis of individual performance & vgki & & & & \\
\hline Variable pay components on the basis of team performance & vgkt & & & & \\
\hline Variable pay components on the basis of company performance & vgku & & & & \\
\hline Variable benefits & vzl & & & & \\
\hline Optional unpaid vacation sabbatical & uu & & & & \\
\hline Competency model & $\mathrm{km}$ & & & & \\
\hline Personalized development plans & pep & & & & \\
\hline Employee portal for training and continuing education & $\mathrm{mp}$ & & & & \\
\hline Management training, external & $\mathrm{mt}$ & & & & \\
\hline Mid and long-term succession plans & mlnp & & & & \\
\hline Domino lists & $\mathrm{dl}$ & & & & \\
\hline Probability assessment for turnover rates & ba & & & & \\
\hline Personalized career paths & $\mathrm{pl}$ & & & & \\
\hline Alternative career paths & aak & & & & \\
\hline Requirements / potential alignments & abp & & & & \\
\hline
\end{tabular}


Table 3. Continue.

\begin{tabular}{|c|c|c|c|c|c|c|}
\hline & Model 1c & & Model 1d & & Model 1e & \\
\hline & Beta & $\mathbf{P}$ & Beta & $\mathbf{P}$ & Beta & $\mathbf{P}$ \\
\hline Talent Infrastructure & 1.364057 & $0.001 * * *$ & 1.425939 & $0.001 * * *$ & 1.112232 & $0.009 * * *$ \\
\hline Size Dummy 1 & .0378418 & 0.891 & -.0046086 & 0.987 & -.0377296 & 0.893 \\
\hline Size Dummy 2 & .0015224 & 0.995 & .004458 & 0.987 & -.0272967 & 0.922 \\
\hline Size Dummy 3 & .6801725 & $0.061 *$ & .6552141 & 0.082 & .671713 & 0.061 \\
\hline Size Dummy 4 & -.0145503 & 0.967 & -.1019273 & 0.801 & .2794939 & 0.493 \\
\hline Industry Dummy 1 & .3303174 & 0.535 & .2887545 & 0.602 & .5238046 & 0.334 \\
\hline Industry Dummy 1 & .3880313 & 0.484 & .3754632 & 0.511 & .5413961 & 0.337 \\
\hline Industry Dummy 2 & .5672545 & 0.315 & .4983534 & 0.398 & .5791386 & 0.335 \\
\hline Industry Dummy 3 & .461597 & 0.388 & .4102836 & 0.458 & .7176466 & 0.186 \\
\hline Detailed job descriptions & -.1847765 & 0.534 & -.2371361 & 0.443 & -.1022027 & 0.737 \\
\hline Detailed qualifications catalogue & .2157462 & 0.411 & .2551201 & 0.348 & .150074 & 0.567 \\
\hline Portal for internal candidates & -.0385718 & 0.898 & -.0372869 & 0.905 & -.2749831 & 0.379 \\
\hline Portal for external candidates & -.3885838 & 0.231 & -.4274173 & 0.215 & -.2716825 & 0.427 \\
\hline Headhunting & -.3249872 & 0.353 & -.3281831 & 0.373 & -.434616 & 0.222 \\
\hline Refer a friend program & -.1388939 & 0.625 & -.1792015 & 0.541 & -.0326061 & 0.908 \\
\hline Assessment Center internal candidates & .3611018 & 0.233 & .2799895 & 0.387 & .2622951 & 0.403 \\
\hline Assessment Center external candidates & -.4801453 & 0.160 & -.5112813 & 0.166 & -.8121311 & $0.029 * *$ \\
\hline Personalized onboarding program & .2443975 & 0.297 & .1973509 & 0.451 & .1715061 & 0.494 \\
\hline Talent pools & -.4000778 & 0.222 & -.3835881 & 0.307 & -.3449411 & 0.335 \\
\hline Automated communications with talent pools via emails/texting & .47738 & 0.400 & .507496 & 0.394 & .8572348 & 0.152 \\
\hline Structured exit management & .3287432 & 0.282 & .3561229 & 0.278 & -.030902 & 0.925 \\
\hline Target setting & 1.2913 & $0.026^{* *}$ & .925794 & 0.225 & 1.372303 & 0.066 \\
\hline Quantitative performance indicators & .2346549 & 0.397 & .2869787 & 0.328 & .3014728 & 0.288 \\
\hline Performance evaluation in several dimensions/categories & -.4916659 & 0.143 & -.5399499 & 0.129 & -.8138742 & $0.023^{* *}$ \\
\hline Potential evaluations, structured and periodic & .1474921 & 0.690 & .1815392 & 0.634 & .210243 & 0.579 \\
\hline Management panels for performance evaluations & -.1058116 & 0.681 & -.154874 & 0.576 & -.263566 & 0.333 \\
\hline Management panels for promotions & .0601883 & 0.839 & .0191834 & 0.951 & .0791771 & 0.797 \\
\hline Recommended distribution of performance categories & .4701114 & $0.098^{*}$ & .4939455 & 0.096 & .5071549 & $0.075^{*}$ \\
\hline Forced distribution & -.8254613 & $0.073 *$ & -.8692931 & $0.067 *$ & -.8335877 & 0.066 \\
\hline 360 degree feedback & .0979783 & 0.754 & .0686231 & 0.836 & .1991845 & 0.537 \\
\hline Variable pay components in general & .3252295 & 0.550 & .5601821 & 0.365 & -.0396858 & 0.950 \\
\hline Variable pay components on the basis of individual performance & -.4231089 & 0.249 & -.4959891 & 0.199 & -.3379457 & 0.393 \\
\hline Variable pay components on the basis of team performance & .4344887 & 0.101 & .4407149 & 0.110 & .4617061 & $0.083^{*}$ \\
\hline Variable pay components on the basis of company performance & -.360432 & 0.351 & -.4518015 & 0.275 & -.3861785 & 0.354 \\
\hline Variable benefits & -.0857042 & 0.739 & -.1642547 & 0.549 & -.3513894 & 0.195 \\
\hline Optional unpaid vacation sabbatical & -.0224516 & 0.937 & -.019009 & 0.950 & -.1019584 & 0.731 \\
\hline Competency model & & & -.1275149 & 0.660 & -.2456204 & 0.373 \\
\hline Personalized development plans & & & .2064299 & 0.495 & -.0203655 & 0.945 \\
\hline Employee portal for training and continuing education & & & .1368972 & 0.537 & .0371273 & 0.867 \\
\hline Management training, external & & & .2983478 & 0.545 & .0618844 & 0.898 \\
\hline Mid and long-term succession plans & & & & & .217107 & 0.540 \\
\hline Domino lists & & & & & .2200618 & 0.532 \\
\hline Probability assessment for turnover rates & & & & & .4587327 & 0.086 \\
\hline Personalized career paths & & & & & .599207 & $0.071^{*}$ \\
\hline Alternative career paths & & & & & .4593924 & 0.138 \\
\hline Requirements / potential alignments & & & & & .1634299 & 0.532 \\
\hline
\end{tabular}

Model 1a=Recruiting Instruments

Model $1 \mathrm{~b}=$ Recruiting, Performance Management Instruments

Model 1c=Recruiting, Performance Management, Compensation Instruments

Model 1d=Recruiting, Performance Management, Compensation, Skill and Competency Management Instruments

Model 1e=Recruiting, Performance Management, Compensation, Skill and Competency Management, Succession Management Instruments

Legend: $\mathrm{P}<0,001$ :***; $^{*}<0,05: * * ; \mathrm{p}<0,1:^{*}$ 
Jens Landwehr: The Use of Talent Management Instruments and Procedures in Germany: A Broad Explorative Study of Effectiveness and Success Factors

Table 4. Results of regression analysis: Talent management processes (dependent variable: success of talent management).

\begin{tabular}{|c|c|c|c|}
\hline & Variable code & Model 4a & \\
\hline & & Beta & $\mathbf{P}$ \\
\hline Talent Infrastructure & Index3481012 & .8857811 & $0.001 * * *$ \\
\hline Size Dummy 1 & Groesse1 & -.2608415 & 0.166 \\
\hline Size Dummy 2 & Groesse2 & .1003501 & 0.613 \\
\hline Size Dummy 3 & Groesse3 & .543855 & $0.053^{*}$ \\
\hline Size Dummy 4 & Groesse4 & .0375399 & 0.885 \\
\hline Industry Dummy 1 & BrancheECP & -.5670589 & 0.276 \\
\hline Industry Dummy 1 & BrancheMFM & -.3041089 & 0.567 \\
\hline Industry Dummy 2 & BrancheESP & -.4289761 & 0.436 \\
\hline Industry Dummy 3 & BrancheDL & -.253393 & 0.622 \\
\hline \multicolumn{4}{|l|}{ Recruiting } \\
\hline Employees outside of recruiting regularly get involved in recruiting processes & stelbes_1 & .042232 & 0.501 \\
\hline Even young very talented employees can obtain management positions in our company & stelbes_2 & .1320555 & 0.110 \\
\hline In our company, we value working experience very highly when filling important managing positions & stelbes_3 & .1546857 & $0.097^{*}$ \\
\hline There are always high numbers of internal applications when open positions are posted & stelbes_4 & .0589841 & 0.499 \\
\hline Internal jobs are frequently filled with applicants who have been informally appointed in advance & stelbes_5 & -.1575584 & $0.037^{* *}$ \\
\hline Often those internal candidates are successful who prior had not been considered for this role & stelbes_6 & .0739434 & 0.440 \\
\hline There are frequent cross divisional and cross functional transfers & stelbes_7 & .1921245 & $0.016^{* *}$ \\
\hline The capabilities of available internal candidates often influence the job design for open positions & stelbes_8 & .1880938 & $0.016^{* *}$ \\
\hline \multicolumn{4}{|l|}{ Performance management } \\
\hline In case your organization has a competency model, is it used regularly and comprehensively & kommod_1 & & \\
\hline The competency model is regulary updated & kommod_2 & & \\
\hline The content of personnel development plans is mostly influenced by the employee himself/herself & einfent_ms & & \\
\hline The content of personnel development plans is mostly influenced by the direct superior & einfent_dv & & \\
\hline The content of personnel development plans is mostly influenced by HR & einfent_pb & & \\
\hline The potential of an employee finds strong consideration in the career planning process & berueck_1 & & \\
\hline \multicolumn{4}{|l|}{ Compensation management } \\
\hline The compensation package can be tailored individually based on employee preferences & comman_1 & & \\
\hline More and more employees take advantage of this service & comman_2 & & \\
\hline Employees with high potential are being compensated significantly higher than other employees & comman_3 & & \\
\hline \multicolumn{4}{|l|}{ Skill and competency management } \\
\hline The career development plans reflect the realistic professional objectives. & sukman_1 & & \\
\hline Training and advanced training plans are seen as self-controllable by our employees. & sukman_2 & & \\
\hline Our Skill and Competency Management considers the employees' personality. & sukman_3 & & \\
\hline Development plans are being implemented with high probability & sukman_4 & & \\
\hline The implementation of personal development plans is regularly supervised & sukman_5 & & \\
\hline \multicolumn{4}{|l|}{ Succession management } \\
\hline $\begin{array}{l}\text { Cross-division or functional career paths are more often initiated through the employer than individual } \\
\text { employees }\end{array}$ & initfuwe & & \\
\hline Global mobility assignments are more often initiated through the employer than individual employees & initausent & & \\
\hline The employees' personal objectives are strongly considered for their career development. & berueck_2 & & \\
\hline The overall personality of an employee finds recognition in their career development & berueck_3 & & \\
\hline The individual situation of each employee is considered when designing time and content of their job & berueck_4 & & \\
\hline The company enables personalized career paths based on the employees' interest and life objectives & nukman_1 & & \\
\hline Maternity leave, sabbaticals and other leave of absent is being considered in career management & nukman_2 & & \\
\hline The use of flexible time-off policy obstructs a structured succession management & nukman_3 & & \\
\hline
\end{tabular}


Table 4. Continued.

\begin{tabular}{|c|c|c|c|c|}
\hline & \multicolumn{2}{|l|}{ Model 4b } & \multicolumn{2}{|l|}{ Model 4c } \\
\hline & Beta & $\mathbf{p}$ & Beta & $\mathbf{P}$ \\
\hline Talent Infrastructure & .9027067 & $0.002 * * *$ & .9062525 & $0.004 * * *$ \\
\hline Size Dummy 1 & -.1092416 & 0.620 & -.2600979 & 0.339 \\
\hline Size Dummy 2 & -.4535582 & $0.035^{* *}$ & -.4952078 & 0.046 \\
\hline Size Dummy 3 & .2759887 & 0.453 & -.3342114 & 0.547 \\
\hline Size Dummy 4 & -.2384558 & 0.354 & -.188159 & 0.501 \\
\hline Industry Dummy 1 & -.4266642 & 0.369 & -.2550171 & 0.626 \\
\hline Industry Dummy 1 & -.0349108 & 0.941 & .1492993 & 0.770 \\
\hline Industry Dummy 2 & -.4114813 & 0.432 & -.1074388 & 0.862 \\
\hline Industry Dummy 3 & -.1042405 & 0.828 & .0110698 & 0.983 \\
\hline \multicolumn{5}{|l|}{ Recruiting } \\
\hline Employees outside of recruiting regularly get involved in recruiting processes & .0213284 & 0.744 & -.0211687 & 0.790 \\
\hline Even young very talented employees can obtain management positions in our company & -.0344788 & 0.715 & -.0263753 & 0.805 \\
\hline $\begin{array}{l}\text { In our company, we value working experience very highly when filling important managing } \\
\text { positions }\end{array}$ & .0558536 & 0.585 & .0766429 & 0.548 \\
\hline There are always high numbers of internal applications when open positions are posted & .0423707 & 0.685 & .0678299 & 0.592 \\
\hline $\begin{array}{l}\text { Internal jobs are frequently filled with applicants who have been informally appointed in } \\
\text { advance }\end{array}$ & -.1283875 & $0.074 *$ & -.0725441 & 0.381 \\
\hline Often those internal candidates are successful who prior had not been considered for this role & .0284435 & 0.773 & .1458616 & 0.239 \\
\hline There are frequent cross divisional and cross functional transfers & .0605978 & 0.499 & .0269297 & 0.802 \\
\hline $\begin{array}{l}\text { The capabilities of available internal candidates often influence the job design for open positions } \\
\text { Performance management }\end{array}$ & .1886698 & $0.027 *$ & .1624356 & $0.097 *$ \\
\hline In case your organization has a competency model, is it used regularly and comprehensively & .0086568 & 0.922 & -.1268 & 0.276 \\
\hline The competency model is regulary updated & .0700618 & 0.391 & .0771163 & 0.462 \\
\hline $\begin{array}{l}\text { The content of personnel development plans is mostly influenced by the employee } \\
\text { himself/herself }\end{array}$ & -.1249292 & 0.234 & -.0188415 & 0.877 \\
\hline The content of personnel development plans is mostly influenced by the direct superior & -.1074201 & 0.388 & -.2528966 & 0.116 \\
\hline The content of personnel development plans is mostly influenced by HR & .0936694 & 0.363 & .1309224 & 0.270 \\
\hline \multicolumn{4}{|l|}{ Compensation management } & $0.003 * * *$ \\
\hline The compensation package can be tailored individually based on employee preferences & & & -.1796482 & 0.181 \\
\hline More and more employees take advantage of this service & & & .2070879 & $0.070^{*}$ \\
\hline Employees with high potential are being compensated significantly higher than other employees & & & .0482976 & 0.630 \\
\hline \multicolumn{5}{|l|}{ Skill and competency management } \\
\hline \multicolumn{5}{|l|}{ The career development plans reflect the realistic professional objectives. } \\
\hline \multicolumn{5}{|l|}{ Training and advanced training plans are seen as self-controllable by our employees. } \\
\hline \multicolumn{5}{|l|}{ Our Skill and Competency Management considers the employees' personality. } \\
\hline \multicolumn{5}{|l|}{ Development plans are being implemented with high probability } \\
\hline \multicolumn{5}{|l|}{ The implementation of personal development plans is regularly supervised } \\
\hline \multicolumn{5}{|l|}{ Succession management } \\
\hline \multicolumn{5}{|l|}{$\begin{array}{l}\text { Cross-division or functional career paths are more often initiated through the employer than } \\
\text { individual employees }\end{array}$} \\
\hline \multicolumn{5}{|l|}{$\begin{array}{l}\text { Global mobility assignments are more often initiated through the employer than individual } \\
\text { employees }\end{array}$} \\
\hline \multicolumn{5}{|l|}{ The employees' personal objectives are strongly considered for their career development. } \\
\hline \multicolumn{5}{|l|}{ The overall personality of an employee finds recognition in their career development } \\
\hline \multicolumn{4}{|l|}{$\begin{array}{l}\text { The individual situation of each employee is considered when designing time and content of } \\
\text { their job }\end{array}$} & $\begin{array}{l}\text { The company enables personalized career paths based on the employees' interest and life } \\
\text { objectives }\end{array}$ \\
\hline Maternity leave, sabbaticals and other leave of absent is being considered in career management & & & & \\
\hline The use of flexible time-off policy obstructs a structured succession management & & & & \\
\hline
\end{tabular}


Table 4. Continued.

\begin{tabular}{|c|c|c|c|c|}
\hline & \multicolumn{2}{|l|}{ Model 4d } & \multicolumn{2}{|l|}{ Model 4e } \\
\hline & Beta & $\mathbf{P}$ & Beta & $\mathbf{P}$ \\
\hline Talent Infrastructure & 1.018326 & $0.002 * * *$ & .7598152 & $0.087 *$ \\
\hline Size Dummy 1 & -.2818806 & 0.296 & -.3133407 & 0.461 \\
\hline Size Dummy 2 & -.4363605 & 0.084 & -.3402887 & 0.534 \\
\hline Size Dummy 3 & -.2932539 & 0.614 & -.1940033 & 0.790 \\
\hline Size Dummy 4 & -.248198 & 0.427 & .0678368 & 0.877 \\
\hline Industry Dummy 1 & .1156808 & 0.841 & .2017389 & 0.780 \\
\hline Industry Dummy 1 & .5078372 & 0.370 & .1857962 & 0.778 \\
\hline Industry Dummy 2 & -.0009511 & 0.999 & .0351826 & 0.969 \\
\hline Industry Dummy 3 & .3155639 & 0.586 & .1261902 & 0.853 \\
\hline Recruiting & & & & \\
\hline Employees outside of recruiting regularly get involved in recruiting processes & -.12622 & 0.174 & -.0735535 & 0.649 \\
\hline Even young very talented employees can obtain management positions in our company & -.0810929 & 0.441 & -.0498201 & 0.712 \\
\hline $\begin{array}{l}\text { In our company, we value working experience very highly when filling important managing } \\
\text { positions }\end{array}$ & .0732782 & 0.584 & -.0154252 & 0.939 \\
\hline There are always high numbers of internal applications when open positions are posted & .0232421 & 0.860 & -.0477897 & 0.811 \\
\hline $\begin{array}{l}\text { Internal jobs are frequently filled with applicants who have been informally appointed in } \\
\text { advance }\end{array}$ & -.0529715 & 0.526 & .0520191 & 0.687 \\
\hline Often those internal candidates are successful who prior had not been considered for this role & .2333906 & 0.087 & .1992869 & 0.392 \\
\hline There are frequent cross divisional and cross functional transfers & .0684533 & 0.517 & .2939046 & 0.127 \\
\hline $\begin{array}{l}\text { The capabilities of available internal candidates often influence the job design for open positions } \\
\text { Performance management }\end{array}$ & .1132433 & 0.276 & -.1108996 & 0.491 \\
\hline In case your organization has a competency model, is it used regularly and comprehensively & -.0639458 & 0.580 & .1062855 & 0.546 \\
\hline The competency model is regulary updated & -.0428333 & 0.739 & -.1714262 & 0.376 \\
\hline $\begin{array}{l}\text { The content of personnel development plans is mostly influenced by the employee } \\
\text { himself/herself }\end{array}$ & -.0558809 & 0.686 & .1033929 & 0.643 \\
\hline The content of personnel development plans is mostly influenced by the direct superior & -.0842115 & 0.610 & .145805 & 0.585 \\
\hline The content of personnel development plans is mostly influenced by HR & .1579854 & 0.224 & .0110431 & 0.954 \\
\hline $\begin{array}{l}\text { The potential of an employee finds strong consideration in the career planning process } \\
\text { Compensation management }\end{array}$ & .3409076 & $0.054 *$ & .2952716 & 0.237 \\
\hline The compensation package can be tailored individually based on employee preferences & -.0576357 & 0.686 & .0132091 & 0.943 \\
\hline More and more employees take advantage of this service & .1048259 & 0.400 & .0667341 & 0.712 \\
\hline $\begin{array}{l}\text { Employees with high potential are being compensated significantly higher than other employees } \\
\text { Skill and competency management }\end{array}$ & -.0269372 & 0.796 & .0486277 & 0.749 \\
\hline The career development plans reflect the realistic professional objectives. & -.0984333 & 0.505 & -.2056505 & 0.360 \\
\hline Training and advanced training plans are seen as self-controllable by our employees. & .2383684 & $0.057^{*}$ & .2314655 & 0.202 \\
\hline Our Skill and Competency Management considers the employees' personality. & -.0304722 & 0.757 & .0419856 & 0.803 \\
\hline Development plans are being implemented with high probability & .1836311 & 0.206 & .2137193 & 0.273 \\
\hline $\begin{array}{l}\text { The implementation of personal development plans is regularly supervised } \\
\text { Succession management }\end{array}$ & .0258398 & 0.833 & .1203227 & 0.592 \\
\hline $\begin{array}{l}\text { Cross-division or functional career paths are more often initiated through the employer than } \\
\text { individual employees }\end{array}$ & & & .0141818 & 0.898 \\
\hline $\begin{array}{l}\text { Global mobility assignments are more often initiated through the employer than individual } \\
\text { employees }\end{array}$ & & & -.108562 & 0.465 \\
\hline The employees' personal objectives are strongly considered for their career development. & & & .0278395 & 0.910 \\
\hline The overall personality of an employee finds recognition in their career development & & & -.0267703 & 0.886 \\
\hline $\begin{array}{l}\text { The individual situation of each employee is considered when designing time and content of } \\
\text { their job }\end{array}$ & & & -.2473398 & 0.268 \\
\hline $\begin{array}{l}\text { The company enables personalized career paths based on the employees' interest and life } \\
\text { objectives }\end{array}$ & & & .131001 & 0.398 \\
\hline Maternity leave, sabbaticals and other leave of absent is being considered in career management & & & -.0106393 & 0.939 \\
\hline The use of flexible time-off policy obstructs a structured succession management & & & .0020805 & 0.988 \\
\hline
\end{tabular}

Model 1a=Recruiting processes

Model $1 b=$ Recruiting, Performance Management processes

Model 1c=Recruiting, Performance Management, Compensation processes

Model 1d=Recruiting, Performance Management, Compensation, Skill and Competency Management processes

Model 1e=Recruiting, Performance Management, Compensation, Skill and Competency Management, Succession Management processes

Legend: $\mathrm{P}<0,001: * * * ; \mathrm{p}<0,05: * * ; \mathrm{p}<0,1:^{*}$

\section{Discussion}

The key finding of this study is that talent management is given high business relevance by talent managers and HR professionals in Germany despite the crisis of 2009. A the same time, HR professionals seem to prefer traditional talent management instruments over innovative processes and procedures which appear to be more successful as measured by expert assessment and objective criteria. Talent managers indeed rate the importance of talent 
management as high or very high, and talent management practice in German organizations is deemed more important than before (and increasing). This is not surprising, given that talent management is rated as one of the pivotal levers for organizations to generate competitive advantages. The study therefore points to an important paradox of talent management: While best practice of talent management is often known, many organizations still rely on traditional instruments which appear to provide less benefit.

As a result, despite the deemed high importance, the talent infrastructure is often weak and - as a result of low levels of success measurement - often the wrong instruments and procedures are being applied. These findings are relevant given the low performance of talent management in many organizations in Germany and the apparent insecurity of talent managers to implement required measures (Moser \& Saxer, 2008). The findings also confirm previous findings that there is not enough evidence based research on talent management available, and that clear success factors of talent management are not reliably identified and understood (Tarique \& Schuler, 2010).

The results support the hypothesis that talent management should be a leadership rather than an HR activity (Moser \& Saxer, 2008). Leadership will be more likely to manage the shift in the talent management paradigm required to increase high regard for its actual success factors. At the same time, in practice many leaders take this task not seriously enough to be successful and often also don't have sufficient knowledge about people behavior.

This study builds on existing theories of talent management and supports the criticism of McKinsey style, selection oriented talent process in favor of development oriented talent management instruments and procedures (Collings \& Mellahi, 2009).

Besides providing evidence for the lack of good talent management in German organizations, the study implies cultural reasons for the preference of traditional talent management in Germany.

Talent management still not well understood

Whereas drivers of the high interest in talent management are increased challenges facing companies in attraction, retention, allocation, and motivation of key personnel, the ineffectiveness and discontent can be explained at least partially with the widespread confusion about talent management both in practice and in research (Lewis \& Heckman, 2006; Collings \& Mellahi, 2009). Many companies still appear to be unclear about the effects and clear benefits of talent management. There is often a lack of available data to identify and measure relevant developments including effects of the demographic change with an expected scarcity of talents in the short and midterm, the very different economic context in which companies make their mid and long-term personnel demand forecasting, as well as what really differentiates (if any) generation $\mathrm{X}$ and $\mathrm{Y}$ entering the workforce. It is also surprising that despite the current internal and external pressures there is still a widespread lack of clear objectives and strategic orientation despite the large pressure to produce qualified talent management output and results.

Lewis and Heckman (Lewis \& Heckman, 2006) were among the first to lament the lack of clarity in defining talent management, and many organizations today still appear to be unclear about the benefits and effects of talent management. They largely follow the workforce segmentation approach to talent management, which is based on identifying current and future A-players in the organizations and trying to attract, retain and develop them. This view was initially claimed by McKinsey consultants who were directly benefiting from consulting projects offering talent management solutions. Their line of thought links the rise of talent management mostly to demands from the business for the need of qualified labor as well as increased HR efficiency (Ulrich, 2002). As a result, the main driver for the increased interest in talent management is its expected business value. According to this line of thought, HR professionals should therefore be guided by serving business objectives and less by the younger generation's personal growth and career aspirations. This 'efficiency hypothesis' also links the early HR transformation argument (Ulrich, 2002) that was synthesized by Jäger (2009) and the hybrid personnel strategy argument. Jäger (2008) argues that modern HR management is driven by increasing efficiencies (driven by Ulrich's three tiered model of HR service centers, Centers of Excellence and Business Partners) combined with the development of an HR value proposition from a business perspective. Collings \& Mellahi (2009) emphasize the strategic element in talent management and linking it to strategic decision making. Furthermore, the authors make a comprehensive effort to further define talent management and propose a model for measuring the effects of talent management. Against this background, the development of talent management instruments and processes has largely been guided by expectations for increased efficiencies, i.e. in post merger integrations, restructurings, or organization's growth strategies.

Driven by these demands from the business, HR tends to neglect the 'development argument', i.e. the perspective of the employee who is increasingly interested in opportunities for personal development. Many younger employees entering the workforce demand more transparent and developmentoriented tools and processes which are currently largely not applied due to the excessive business orientation of HR. Our findings therefore confirm largely the arguments of the 'critical' talent management research, who criticize the focus on A-players in talent management (Tarique \& Schuler, 2010; McDonnell et al 2010). However, there are very few to no studies discussing the effectiveness of specific talent instruments and processes from a people perspective.

High importance but weak infrastructure

The results show that in many cases companies have begun to design talent management strategies, which 
include specific activities in the areas of job design, performance management, learning \& development, rewards and career/succession management, with differing levels of breadth, structure, and integration with the overall business strategy. However, due to the weak infrastructure there is no best practice tool set in organizations and companies often use in-house solutions or fragmented processes or limit their activities to specific target groups. As a result, talent management processes developed highly heterogeneously, often as in-house solutions with little or no IT support, external benchmarking and use of metrics. In many areas, this situation was amplified by the recession of 2008 with increased cost pressures often directed towards HR. As a result, the opportunities under which companies design and implement talent solutions varied widely and systems and processes are often further reduced. While this context frequently leads to business and cost oriented solutions, such processes often sufficiently lack the employee perspective and latest psychological research on organizational behavior and motivation theory (Moser \& Saxer, 2008; Jäger 2008). In few companies, talent management developed into the type of new core HR process, in many companies the topic received little or no top management attention, and the talent infrastructure in many companies (IT, metrics, benchmarks) remains very weak. Recently, increasing challenges to acquire, retain and develop key talents have strengthened the role of talent management in many organizations which is also reflected by the high interest in the present study.

A good example of the combination of development and efficiency emphasis is the increasing importance of internal job boards, which are often seen as internal development opportunities. Here, employees can apply even if cross-division and often without involving their superiors wide on vacancies. This is often in line with the employees' desire for personalized developmental pathways, and is also better for the company as enterprisewide fluctuations in supply and demand can be offset and delays and costs through external recruitment can be avoided. This argument hints at the possibility that development and efficiency hypotheses are not conflicting explanations for good talent management. Often, the mobilization of the internal labor market is also less expensive than external recruiting, especially when combined with internal trainings and cross functional mobility. Cappelli (2008) provides many examples of the convergence of development and efficiency arguments. However there are limits to this convergence: Individual freedom of choice and organizational requirements must be negotiated to find an organizational and individual optimum. As an example, it can sometimes be cheaper to buy externally if internal training cost and personal/family benefits are calculated in. Therefore, it overall appears that in the field of talent management there remains large room for quality improvements.

Success factors not consistently applied

Our results show that success critical instruments are not sufficiently applied in German organizations. It appears that the practice of talent management in most organizations is a mix of the normative and critical schools of thought. However the results shows that development oriented instruments such as potential, personal objectives and alternative career paths are more successful than a pure business orientation of talent management. The results therefore confirm the 'critical' view of talent management which emerged in parallel to the McKinsey school of thought (Tarique and Schuler; 2009).

The second line of thought links the rise of talent management to demands from the labor force. According to this line of thought, organizations should offer talent management programs in response to an increasing demand from younger-generation professionals for meaningful work, work/life balance, fairness and transparency in organizations. According to this hypothesis, talent management owes its rise to a change in values by new generations of professionals with implications on how organizations manage human capital internally, from recruiting to performance management, appraisal and compensation processes. This hypothesis, labeled here as value hypothesis, is based on the development argument of talent management (Tarique and Schuler, 2009; Beechler and Woodward, 2009). According to this view, the rise of talent management is due to a primarily demand-based change in expectations of younger-generation professionals who demand higher levels of transparency, a higher level of work/life balance, career options that are attractive and motivating to them, and argues that this is the major cause of talent management. This view on the rise of talent management is largely based on Richard Florida (2005) and others' (Deloitte Research study on change in values) description of generational changes (XY generation) and has been picked up by modern HR management as motivator's dilemma (Losey, Ulrich, Meisinger, 2003).

Meyer, Kirby (2010) have linked this line of thought to the increased desire to create transparency which spills over to many life venues. According to this line of thought, the rise of talent management is based on the fact that many young people have different expectations about their career lives including the expectation to find a better work/life balance and do meaningful work. Transparency in business is considered to be one of the major influences on business in the coming years. Closely connected to transparency in talent management decisions is the concept of interactional and procedural fairness. A wide range of empirical evidence adds especially these two fairness ideas to the list of important issues of modern and future HR management. Pfeffer (2001) responded to McKinsey's approach by restating Deming's theory that the attributes of the system in which the person works need to be improved in order to increase talent output. He also emphasized the importance of teamwork, claiming that the overemphasis on the individual talent hurts organizational effectiveness.

In sum, German organizations are often not responding 
well enough to the increasing pressures on their talent management programs in responding to the wide range of requirements, and are in practice applying effective programs. Also, executives and employees often rate the talent management in German organizations as insufficient and actual metrics also point to a quality deficit. Despite its high importance rating, there is not a good infrastructure and effective instruments are not used often enough, not enough differentiation possible, not enough alternatives, not enough potential assessments and not enough differentiation possible (H2), not enough openness and flexibility (H3) and other sustainable factors of a successful talent management. Openness and flexibility accommodate motivation requirements and are, from fairness research studies, also known to be important factors.

In contrast, the identified success factors indicate that the many successful talent instruments are strongly linked to the development argument. This is particularly significant in light of the differentiating recruiting tools, the talent pool self-application, as well as the strong significance of the internal job market, as shows in the graphic below.

People strategies in many organizations weak or not existing

A further possible explanation for bad talent management in practice is, that the underlying people theory is wrong. Mostly, talent management refers to recruitment and development of A-Performers (Collings \& Mellahi; 2009) and the implication is that there are critical workforce segments who contribute disproportionately higher to company success compared to other employees. As a result, many organizations don't use success critical instruments and processes but rather focus on the wrong instruments and processes. Also, in many organizations, there is a large insecurity about the right approach to talent management with the result of conflicting approaches. Discussions are very dogmatic and talent management is often not managed well, due to a lack of orientation and use of best practice. Generally, the focus is too much on performance rather than potential and development, on hierarchy rather than enabling communication and exchange of ideas.

Our results therefore lead to the conclusion that the development argument used by the critics of the McKinsey approach to talent management is correct (Tarique and Schuler, 2009; Beechler and Woodward, 2009). In light of the current lines of thoughts on talent management the study therefore offers support for the critical view of the McKinsey approach. It seems, organizations focus too much on middle managers and upwards, as talent activities are associated with internal costs and often don't immediately pay-off. In addition, most managers don't seem to pay too much attention to a rigid execution of talent management processes further impeding the quality. Finally, the widespread use of talent instruments used specifically for the administration, control or resource planning of talents indicates that talent management in most organization further shows the short term cost/benefit orientation of talent management. As a results, even though the importance of talent management has reached the mind of the people in charge of HR, nowadays talent management is still perceived as a tool, which first of all has to be efficient. This way, the complexity and long-term orientation that are necessary to face current and future labor challenges are easily overlooked. However, instead of applying the success factors and bringing HR into the driver seat of corporate development, it applies a very traditional HR model.

This finding is relevant as it delivers a plausible explanation why talent management does often not lead to the expected success and also links the lack of success to the use of instruments. This study not only provides an overview over the current research, it also identifies the weakness of talent management and thus contributes to the overall improvement of talent management performance in German organizations. Furthermore, it provides an answer to the question whether the increased importance is driven by the requirements from the workforce or by the business demands. Our results show that the success-critical instruments and procedures are not used consequentially and that talent managers seem to rely on rather traditional instruments and processes.

Overall, the success factors identified such as increased levels of transparency should be implemented in such as a way to create win/win scenarios serving both organizational and individual benefits: Where employees have a clean and transparent perspective on career opportunities they are more likely to do what is expected of them and in return companies can better calculate with stable or improved performance levels and less fluctuation. Further research will determine a more conclusive relationship for specific talent management processes and procedures.

Hier das noch weiter erklären, kann ich (was sind die deficiencies in Deutschland)

\section{Summary of Results}

- Despite the high significance of talent management, the appropriate infrastructure often is relatively weak (in terms of performance measurement, IT support, established external benchmarks)

- Human resource managers often assess the impact of tools differently than what was found as actual effectiveness of consistent success on the talent management company as a whole.

- Often the most effective tools are relatively little used. Examples are:

- Use of structured exit management

- Recommended distribution of performance levels

- Use of management panels

- Options to choose "alternative" career paths (i.e. expert or project-specialized career)

- Personalized career plans

- Managers should take their responsibility for talent management more seriously, as especially their participation is of paramount importance for the success. 
In summary, the openness and transparency of the system seem to be advantageous. Many scholars and practitioners have been emphasizing the need for more developmentoriented talent activities including career autonomy in combination with employee-centered career paths and application processes for quite some time (i.e. Jäger 2008; Capelli 2008; Benko 2008). The present study confirms these claims.

\section{References}

[1] Aston, C. and Morton, L. (2005), 'Managing Talent for competitive advantage,' Strategic HR Review, 4: 28-31.

[2] Arthur, M. B. (1994) 'The boundaryless career: A new perspective for organizational enquiry,' Journal of Organizational Behaviour, 15, 295-306.

[3] Axelrod, B., Handfield-Jones, H. and Michaels, E. (2002), 'A new game plan for C players,' Harvard Business Review, January, 81-88.

[4] Becker, B., Huselid, M., Ulrich, D. (2009), 'The HR Scorecard. Linking people, strategy and performance'.

[5] Beechler, S., \& Woodward, I. C. (2009), 'The global war for talent,' in: Journal of International Management, 15(3), 273285 .

[6] Bernardin, H. J., Cooke, D. K. and Villanova, P. (2000), 'Conscientiousness and agreeableness as predictors of rating leniency,' in: Journal of Applied Psychology, 85, 232-234.

[7] Boselie, P., Dietz, G. and Boon, C. (2005) 'Commonalities and contradictions in HRM and performance research', Human Resource Management Journal, 15, 67-94.

[8] Boxall, P. and Purcell, J. (2008), 'Strategy and Human Resource Management', $2^{\text {nd }}$ Edition, Basingstoke and New York: Palgrave Macmillan.

[9] Brown, P., Tannock, S. (2008) 'Education, meritocracy and the global war for talent', in: International Journal for Human Resource Management, Received 15 July 2008; final version received 8 December 2008

[10] Busck, O., Knudsen, H., Lind, J. (2010), 'The transformation of employee participation: Consequences for the work environment,' in Economic \& Industrial Democracy, August 2010, Vol. 31 Issue 3, 284-305, 21p.

[11] Cappelli, P. (2008), 'Talent Management for the Twenty-First Century,' in Harvard Business Review, March 2008, 74-81.

[12] Cappelli, P. (2008), 'Talent on Demand, Managing Talent in an age of uncertainty'.

[13] Christiansen, R. (2010), 'Roadmap to strategic HR: Turning a great idea into a business reality'.

[14] Clutterbuck, D. (2010), 'Talent and succession planning,' in HR Vision, January 2010.

[15] Collings, D. G. and Mellahi, K. (2009), 'Strategic Talent Management: A review and research agenda,' in: Human Resource Management Review, 19: 4, 304-313.

[16] Cooper, C., Kenneth, K., Carlton, C. (2000), 'Effective
Competency Modeling and Reporting - A step-by-step guide for improving individual and organizational performance'.

[17] De Mello, Cristina; Wildermuth, Souza; Pauken, Patrick David (2008), 'A perfect match: decoding employee engagement - Part II: engaging jobs and individuals,' in Industrial \& Commercial Training; 2008, Vol. 40 Issue 4, 206$210,5 \mathrm{p}$.

[18] Fietze, S., Holst E., \& Tobsch, V. (2010). ,Germany's Next Top Manager: Does Personality explain the Gender Career Gap?' Joint Research and Discussion Paper No. 3. International Institute of Management, University of Flensburg and Department of Border Region Studies, University of Southern Denmark, Flensburg/Sonderburg.

[19] Gabler, N. (2007), Personalentwicklungsjahrbuch.

[20] Germain, J. (2010), 'How to DRIVE your Troublesome Talent forward to success,' in Manager: British Journal of Administrative Management, Spring 2010, Issue 70, p18-19, $2 \mathrm{p}$.

[21] Greenhaus, Parasuraman, \& Wormley (1990), AMJ.

[22] Groysberg, B., Nanda, A., Nohria, N. (2004), 'The risky business of hiring stars.' in Harvard Business Review 1-10 (May 1).

[23] Groysberg, B., McLean, A., Nohria, N. (2006), 'Are leaders portable?' in Harvard Business Review 1-10 (May 1).

[24] Groysberg, B., McLean, A., Nohria, N. (2008), 'How star women build portable skills' in Harvard Business Review 1-8 (February).

[25] Hough, L. M., \& Oswald, F. L. (2008), 'Personality testing and I-O psychology: Asking questions, offering answers, discussing unknowns, and providing direction,' in: Industrial and Organizational Psychology, 1 (3).

[26] Jäger, W. (2009), Talent Management ist Personalmanagement, in Talent Management, Strategien, Umsetzung, Perspektiven“

[27] Knoblauch, J. (2010), 'Die Personalfalle. Schwaches Personalmanagement ruiniert Unternehmen,' Campus 2010

[28] Lewis, R. E., \& R. J. Heckman (2006), 'Talent management: A critical review,' in Human Resource Management Review, 16: $139-154$.

[29] Losey, M., Ulrich, D., Meisinger, S. (2010), 'The Future of Human Resource Management, 64 Thought Leaders explore the critical HR issues of today and tomorrow'.

[30] Martin, J. and Schmidt, C. (2010), 'How to Keep Your Top Talent,' in Harvard Business Review; May 2010.

[31] McDonnell, A., Lamare, R., Gunnigle, P., Lavelle, J. (2010), 'Developing tomorrow's leaders-Evidence of global talent management in multinational enterprises.' In: Journal of World Business; Apr2010, Vol. 45 Issue 2, p150-160, 11p.

[32] Meifert, M. T., (eds.) (2010), 'Strategische Personalentwicklung. Ein Programm in acht Etappen,' Springer 2010.

[33] Meyer, C.; Kirby, J. (2010), 'Leadership in the age of transparency', in: Harvard Business Review, Apr2010, Vol. 88 Issue 4. 
[34] Michaels, E., Handfield-Jones, H. and Axelrod, B. (2001), 'The War for Talent', Boston, Harvard Business School Press.

[35] Moser, R., Saxer, A. (2008), 'Retention Management für High Potentials, Konzeptionelle Grundlagen - empirische Ergebnisse - Gestaltungsempfehlungen,' Vdm Verlag Dr. Müller 2008.

[36] Pfeffer, J (2001). 'Fighting the War for Talent is Hazardous to Your Organization's Health.' Organizational Dynamics, 29(4), 248-259.

[37] Pfeffer, Jeffrey and Robert I. Sutton (2006) 'Evidence-Based Management' in Harvard Business Review, 84(1), 2006, 6374.

[38] Rammstedt, B. (2007), 'Who worries and who is happy? Explaining individual differences in worries and satisfaction by personality.' in: Personality and Individual Differences, 43, 1626-1634.

[39] Sliwka (2008), 'Transparency, Inequity Aversion, and the Dynamics of Peer Pressure in Teams: Theory and Evidence,' in: Journal of Labor Economics 26 (2008), 693-720.

[40] Stage \& Houghton (2009), 'IMI's Aspire program feeds its senior leader pipeline through self nominations,' in Wiley Interscience, July/August 2009.

[41] Stage, Victoria, Houghton, Russell (2009), 'IMI's Aspire program feeds its senior leader pipeline through selfnominations,' in Global Business \& Organizational Excellence, Jul/Aug 2009, Vol. 28 Issue 5, 16-25.
[42] Stahl, G. K., Bjorkman, I., Farndale, E., Morris, S. S., Stiles, P., Trevor, J. \& Wright, P. M. (2007), 'Global Talent Management: How Leading Multinationals Build and Sustain Their Talent Pipeline,' Faculty \& Research Working Paper. Fontainebleau, France, INSEAD.

[43] Tansley (2011), "What do we mean by the term "talent" in talent management?", Industrial and Commercial Training, Vol. 43 Iss: 5, pp. 266.

[44] Tarique \& Schuler (2009), 'Global talent management: Literature review, integrative framework, and suggestions for further research,' in Journal of World Business, April 2010, Vol. 45 Issue 2, 122-133.

[45] Tett, R. P., \& Burnett, D. D. (2003). 'A personality trait-based interactionist model of job performance.' Journal of Applied Psychology, 88, 500-517.

[46] Ulrich, D. (2008), 'The HR value proposition'.

[47] Ulrich, D. (2006), 'Delivering results: A new mandate for HR Professionals'.

[48] Ulrich, D. (2006), 'Human Resource Champions, What are the top five business challenges your executives must pay attention to?'

[49] Van Nuland \& Hanke, 'Exploring the motivation jungle: Predicting performance on a novel task by investigating constructs from different motivation perspectives in tandem,' in International Journal of Psychology; August 2010, Vol. 45 Issue 4, 250-259. 